\title{
THE IMPACT OF INCLUSIONARY ZONING ON TORONTO'S NEIGHBOURHOODS
}

\author{
by \\ Matthew Kruger \\ BA, Western University, 2016 \\ A Major Research Paper \\ Presented to Ryerson University \\ In partial fulfillment of the requirements for the degree of \\ Master of Planning \\ in \\ Urban Development
}

Toronto, Ontario, Canada, 2018

(c) Matthew Kruger 2018 


\section{AUTHOR'S DECLARATION FOR ELECTRONIC SUBMISSION OF A MRP}

I hereby declare that I am the sole author of this MRP. This is a true copy of the MRP, including any required final revisions.

I authorize Ryerson University to lend this MRP to other institutions or individuals for the purpose of scholarly research.

I further authorize Ryerson University to reproduce this MRP by photocopying or by other means, in total or in part, at the request of other institutions or individuals for the purpose of scholarly research.

I understand that my MRP may be made electronically available to the public. 


\title{
THE IMPACT OF INCLUSIONARY ZONING ON TORONTO'S NEIGHBOURHOODS
}

\author{
(C) Matthew Kruger 2018 \\ Master of Planning \\ in \\ Urban Development \\ Ryerson University
}

\begin{abstract}
Toronto has faced unprecedented growth in the condominium market over the last decade. Today, prices are unaffordable for many, leading to the proposed inclusionary zoning regulations by the Ministry of Municipal Affairs in December of 2017. The proposed regulations would undoubtedly impact financial aspects of residential real estate development, setting aside a maximum of ten percent of units for affordable ownership. Nevertheless, the adoption of inclusionary zoning in Toronto's Official Plan and Zoning By-law has the potential to provide affordable home ownership for designated low-income inhabitants. The goal of this document is to analyze the financial impacts of the proposed inclusionary zoning regulations on current land prices and condominium price per square foot assumptions.
\end{abstract}

Key Words: Inclusionary Zoning, Affordable Housing, Toronto, Residual Land Value 


\section{ACKNOWLEDGEMENTS}

I want to thank my supervisor, Professor David Amborski, as I could not have completed this paper without his consultation and guidance, providing me insight on his years of experience in the urban planning in the City of Toronto, affordable housing, and city building industry. Professor Amborski is the founding director of the Centre for Urban Research and Land Development, and is the academic director of Ryerson's City Building Institute.

I would also like to thank my second reader, Jonathan Karavos for providing an academic review of all my work throughout the entire process, appraising and assessing the countless drafts, ensuring quality and accuracy of all data, facts, figures, etc. Jonathan currently works at Metropia, a privately owned and highly respected real estate developer recognized for creating authentic Communities in both the Greater Toronto Area and Calgary, focusing on community building, urban renewal and design innovation. 


\section{TABLE OF CONTENTS}

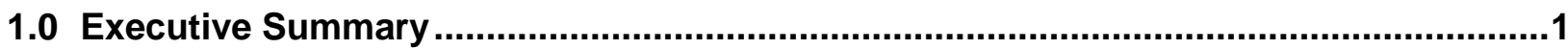

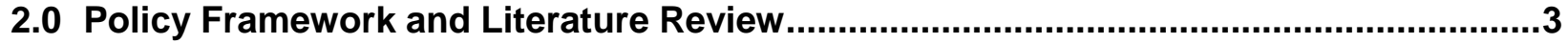

2.1 Priority of Affordable Housing in Toronto ............................................................

2.2 Affordable Housing Context and Timeline ...................................................... 4

2.2.1 Federal: National Housing Strategy ................................................. 4

2.2.2 Provincial: Ontario's Long Term Affordable Housing Strategy Update ......5

2.2.3 Municipal: Housing Opportunities Toronto ...........................................6

2.2.4 Open Door Program \& DC Rebate Program .......................................

2.3 Inclusionary Zoning ......................................................................................

2.3.1 Inclusionary Zoning Policy Timeline..................................................11

2.3.2 Bill 7 - Draft Inclusionary Zoning Regulations .................................. 14

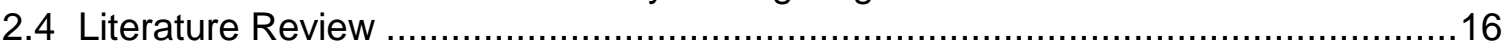

2.4.1 The Economics of Inclusionary Development ..................................16

2.4.2 Inclusionary Housing in the U.S.: Prevalence, Impact, and Practices .....19

2.4.3 Land Value Capture \& Inclusionary Zoning.........................................22

2.4.4 Inclusionary Zoning in International Perspective ................................22

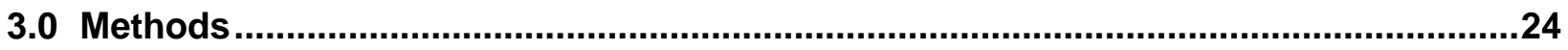

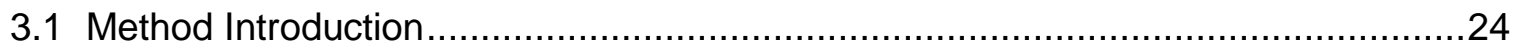

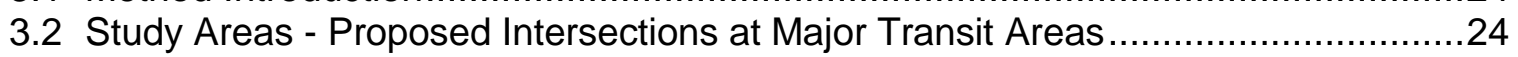

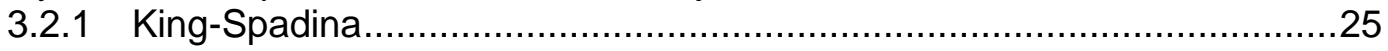

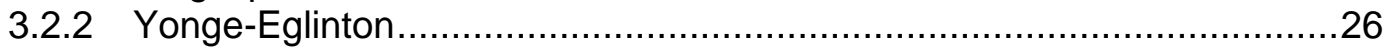

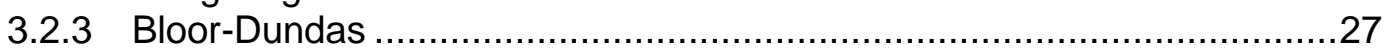

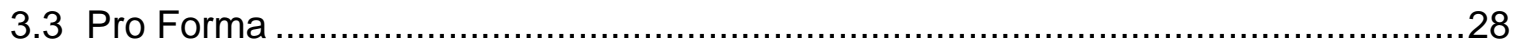

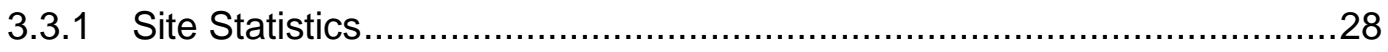

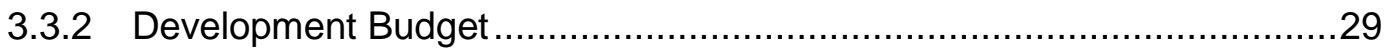

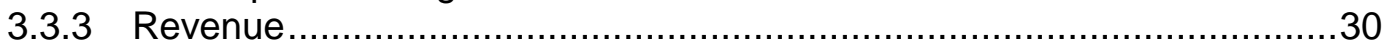

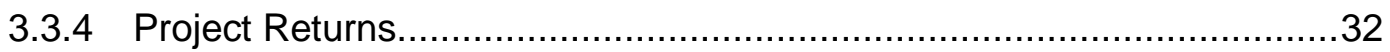

3.4 Inclusionary Zoning Impact Analysis....................................................... 33

4.0 Problem Investigation and Results..........................................................................35

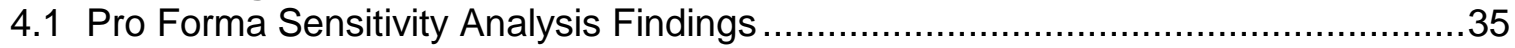

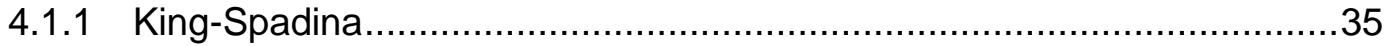

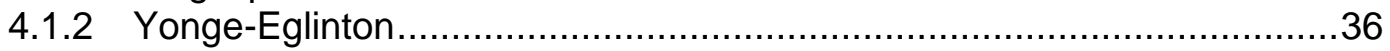

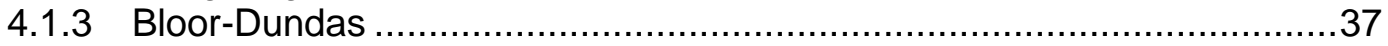

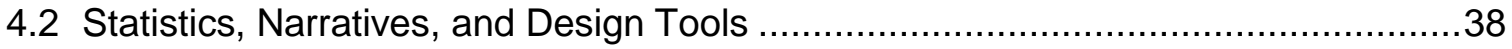

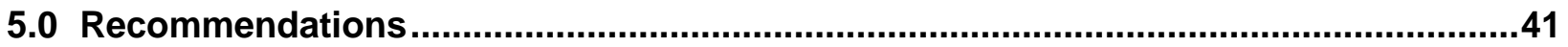

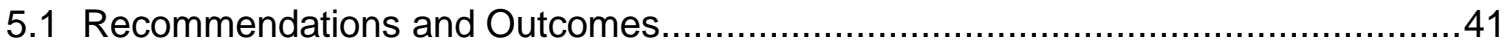

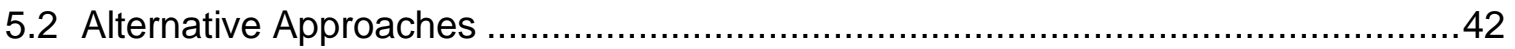

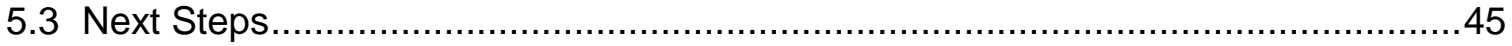




\section{LIST OF TABLES}

Table 1 - Toronto's Average Market Rent (AMR) By Unit Type ….................................... 9

Table 2 - 2017 Open Door Program Approvals.............................................................11

Table 3 - Land Residual of a Development at Different Set-aside Levels ............................19

Table 4 - Condominium Prices in Toronto's Key Intersections ...........................................20

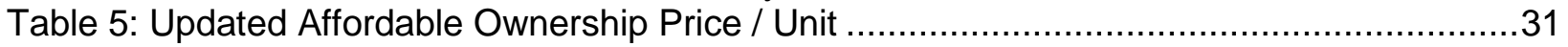

\section{LIST OF FIGURES}

Figure 1 - HOT Action Plan: New Affordable Rental Homes Approved \& Completed.................8

Figure 2 - HOT Action Plan: New Affordable Ownership Homes Approved \& Completed ...........8

Figure 3 - Toronto Home Ownership Costs as \% of Median Household Income.....................17

Figure 4 - Land Purchases within 500m the Intersection of King St W \& Spadina Ave .............26

Figure 5 - Spadina Avenue Looking North................................................................26

Figure 6 - Land Purchases within 500m the Intersection of Yonge St \& Eglinton Ave..............27

Figure 7 - RioCan's Yonge Eglin Centre Redevelopment ................................................27

Figure 8 - Land Purchases within 500m the Intersection of Bloor St W \& Dundas St W ..........28

Figure 9 - A Rendering of Choice Properties' Bloor-Dundas Redevelopment .........................28

Figure 10 - Toronto Rents and Affordability by Income Band..............................................32

Figure 11 - Greater Toronto Area Housing Prices Since 2006, by Housing Type ....................34

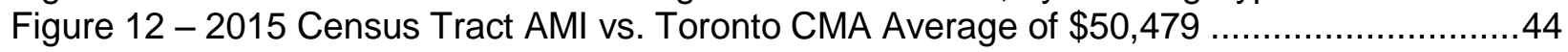

\section{LIST OF APPENDICES}

Appendix A - Pro Forma for Archetypal King-Spadina Mixed-Use Development ....................46

Appendix B - Pro Forma for Archetypal Yonge-Eglinton Mixed-Use Development ...................47

Appendix C - Pro Forma for Archetypal Bloor-Dundas Mixed-Use Development......................48

Appendix D - Residential Land Transactions within 500m of King-Spadina Node...................49

Appendix E - Residential Land Transactions within 500m of Yonge-Eglinton Node .................50

Appendix F - Residential Land Transactions within 500m of Bloor-Dundas Node....................51 


\subsection{EXECUTIVE SUMMARY}

In December of 2017, the Ministry of Municipal Affairs released draft inclusionary zoning regulations, determining the provision of affordable ownership units in residential developments with twenty or more units. Defined by Toronto's Official Plan and Zoning By-law, the definition of affordability will have an impact of the financial considerations of existing and future real estate development. The proposed regulations entail: a maximum of ten percent (10\%) of units to be set aside for affordability, an activation number of twenty (20) or more units in new residential developments, and a forty percent (40\%) rebate from the city regarding reduced proceeds due to the affordable units. These broad policies are intended to create new affordable housing ownership opportunities in an increasingly expensive city (Ministry of Housing, 2016). Notwithstanding, the new policies will undoubtedly have a significant impact on specific real estate develop price measures, such as land price / buildable square foot and condominium price / square foot. The aim of this MRP is to uncover the greater impacts stemming from the proposed provincial inclusionary zoning measures, enacted to encourage municipalities to create affordable housing.

The key method for processing the impacts of the inclusionary zoning regulations was derived from pro forma analysis, comparing prices with a desired financial return. The three intersections were selected based on the high volume of recent land transactions (occurring in the last $10_{+}$

years) and the likely delineation of being designated as a High Density Transit-Station area. These areas were specifically mentioned in the proposed regulations to provide the maximum of ten percent (10\%) affordable units, while other areas of the city have the potential to be subject to the requirement of only five percent (5\%) affordable units. Specifically, the method relied upon measuring the price impacts of inclusionary zoning on land price / buildable square foot and 
condominium price / square foot, assuming a $2.0 x$ equity multiple and fifteen percent (15\%) cost over budgets. Recognized as a residual land value analysis, the function of the pro forma is to first provide reasonable input assumptions for construction costs, consultant costs, and other pivotal development costs before determining what the developer can pay for the land. The same residual analysis function is also used for determining the impact on market condominium price / square foot. These methods were chosen because pro formas have the ability to provide a strong impression of the current financial reality of the private companies in the development industry, giving primary insight on the process of development from the acquisition of raw land to eventual construction and building occupancy.

All three models concluded a much higher land cost and condominium price / square foot when including the inputs for the proposed inclusionary zoning regulations. As the real estate development market currently stands, the provision of affordable units will not occur without creative financing structures from private developers and city policy-makers. To avoid a comprehensive standstill in the development and construction of residential condominiums, a crucial shift in land prices and market rate prices will have to adjust to ensure the current and future provision of both market-rate and affordable condominium units. This MRP explored the key findings of land prices dropping an average of $\$ 63.6$ / buildable square footage while incorporating inclusionary zoning. In reality, the burden of the cost will be placed on market forces in addition to land owners across the city. 


\subsection{POLICY FRAMEWORK AND LITERATURE REVIEW}

\subsection{Priority of Affordable Housing in Toronto}

The creation of affordable housing is of high priority in Toronto, as recent census data identify a population increase of 116,511 (4.45\% increase) in the City of Toronto from 2011 to 2016 (Statistics Canada, 2016). Comprising of pre-amalgamation boroughs, this estimate doesn't include the estimated Census Metropolitan Area (CMA) of 5,928,040, when including highly populated areas such as Mississauga, Richmond Hill, and Brampton (Statistics Canada, 2016). Conceptually, the affordable housing analysis can be centred on two key variables: housing stock growth (supply) and population growth (demand).

Typically enacted by ruling government powers, solutions to the affordable housing dilemma derive from legislature such as inclusionary zoning and/or secondary units. These solutions are important in establishing and maintaining a high standard of living, local and foreign investment, and a diverse and highly skilled work force in Toronto. However, while these innovative government solutions have merit, it is worth exploring their overall effectiveness. Are solutions such as inclusionary zoning addressing the root of the problem, or are they reactionary measures? The inherent corrective nature of inclusionary zoning adds to criticisms of recent government initiatives as being reactionary as opposed to preventative (Gordon, 2017). The determination of a remedy for housing affordability is crucial for the future of Toronto and its residents.

On December 8th, 2016, Bill 7, the Promoting Affordable Housing Act, was given royal assent. In short, The Ministry of Housing is enabling municipalities to require affordable housing units in any residential development (Ministry of Housing, 2016). Known as inclusionary zoning, this practice 
is based on the two key requirements: the set-aside percentage and affordability requirements. The former refers to the number of units that are required to be below market price, while the latter refers to the income threshold required to determine if a household is eligible for an affordable unit.

While no specific inclusionary zoning policies have been implemented in Toronto, the Province released draft guidelines on December $18^{\text {th }}, 2017$, outlining a summary of the proposed regulations regarding how inclusionary zoning would operate in each municipality (Ministry of Municipal Affairs, 2017). While the broader impact of these regulations will be explored further in this document, in short, the regulations call for twenty (20) unit activation rate, five $(5 \%)$ to ten (10\%) percent requirement affordable units, and the provision of affordable ownership, as opposed to rental units. The intention of this document is to outline the history of affordable housing policy, detail comparable inclusionary zoning regulations in municipalities in the Unites States, and use an analytical approach to develop feasibility of the program in Toronto while providing program recommendations.

The following text outlines the history and progress of affordable housing in Toronto since the mid-1990's. Using the context of various municipal, provincial, and federal government initiatives and policies, the intent is to provide a comprehensive background on the origin and current standing of Toronto's affordable housing conditions.

\subsection{Affordable Housing Policy Context and Timeline}

\subsubsection{Federal Background}

Called "Canada's First National Housing Strategy," The Liberal Government's 10-year, \$40 Billion will begin in 2018 , planning to set out various policy objectives and action plans that encourage 
the development and access of affordable housing throughout Canada. The Housing Strategy has lofty goals, including a fifty percent $(50 \%)$ reduction in chronically homeless shelter users, one hundred thousand $(100,000)$ new housing units created, and three hundred thousand $(300,000)$ households provided with affordability support through the Canada Housing Benefit. In short, the money moves through the provincial governments, and then into non-profit housing, supportive housing, and public housing in each respective municipality (Canada's National Housing Strategy, 2017). While the federal funding structures and programs is beyond the scope of this paper, it is important to understand conceptually the source of funding for Inclusionary Policies set forth by the Ontario Provincial Government.

\subsubsection{Provincial - Ontario's LTAHS Update, 2016}

Provincially, there is recent emphasis and direction towards affordable housing. In the aforementioned December 2016 royal assent of the Promoting Affordable Housing Act, the government updated the Long-Term Affordable Housing Strategy (originally released in 2010). In this update, the province creates a framework for various policy directions for affordable housing, comprising of: portable housing strategies, supportive housing strategies, indigenous housing strategies, ending homelessness, and amendments to the Residential Tenancies Act (2006). Overall, the updated strategy has broad goals of: "increasing the supply of affordable housing, supporting people, and ending chronic homelessness by 2025." These updated provincial strategies did not come empty-handed, with a budgeted commitment of spending up to $\$ 100$ million for supportive housing annually, and \$294 million for the Community Homelessness Prevention Initiative in $2016 / 2017$. The overall goal of the update was the mandate of every person having the right to an "affordable, suitable, and adequate home" (LTAHS, 2016). In turn, this umbrella goal of the provision of housing to all Ontarians lead to the goal of introducing inclusionary zoning, enabling municipalities to enact inclusionary zoning, "giving all municipalities 
the ability to require private developers to include affordable housing units in their development proposals (LTAHS, 2016).

Vaguely-worded, the strategy enables each of Ontario's four hundred and forty-four (444) municipalities to implement the finalized regulations, but they only exist in draft form. However, this broad policy is inherently problematic, as every municipality has their own unique needs. The president of CityHousing Hamilton and Ward 5 Councillor Chad Collins recently noted in a February 2018 CBC interview that umbrella inclusionary zoning regulations "won't work" in Hamilton because of affordability difference between rental housing and ownership, along with the unit number trigger (i.e. minimum of twenty units requires inclusionary zoning). Additionally, he noted that broad policies are essentially tailored for the City of Toronto because of population and demographic composition (CBC, 2018).

\subsubsection{Municipal - HOT Plan}

In the Toronto context, city council endorsed the Housing Opportunities Toronto (HOT) Affordable Action Plan 2010-2020, aiming to provide a "road map" to guide municipal investments towards the City of Toronto in partnerships with the provincial and federal governments. Adopted over eight (8) years ago, The HOT Action Plan is guided by the Toronto Housing Charter which states: "it is the policy of the City of Toronto that fair access to a full range of housing is fundamental to strengthening Toronto's economy, its environmental efforts, and the health and social well-being of its residents and communities (Toronto Housing Charter - Opportunity for All, 2017)." In short, the charter is designed to direct city council when considering decisions regarding the planning and financial implications of affordable housing. Comprising of sixty-seven (67) recommendations the action plan strategically lays out how Toronto can achieve a lofty goal of producing at least 1,000 new rental homes annually, and 200-400 new home ownership opportunities annually (note 
that affordable ownership target increased to 400 units per year as per a December 2015 City Council decision).

The annual release of the HOT progress report since 2014 adequately provides an update on the progress of the provision of a variety of affordable housing initiatives taking place in Toronto. As seen in Figures $\mathbf{1}$ and 2, the data is visually divided by approvals and completions, with rental units only achieving the target construction completion rate in 2012, with 1,170 units completed. For affordable home ownership, completions reached the HOT action plan targets in 2010, 2012 and is projected to in 2018 and 2019. In terms of approvals, 2016 \& 2017 combined were the highest year for rental home approvals, with City Council approving applications amounting to approximately 1,771 affordable units total. For ownership, 2016 \& 2017 were also the highest twoyear total for affordable home ownership approvals, with a projected 608 affordable home ownership opportunities approved for either Zoning By-law Amendments, Official Plan Amendments, or Site Plan Control. The substantial increase in affordable rental and ownership opportunities in Toronto reflects the 2016 launch of the Open Door Program, coinciding with municipal incentives for the private sector to provide affordable housing. Calling for the annual investment of $\$ 484$ million, primarily sourced from the federal and provincial governments, by reutilizing savings achieved in other administrative areas such as health, immigration, corrections, and emergency services (Toronto Housing Charter - Opportunity for All, 2017). The charter prioritizing the "housing first approach," aiming to deliver funding and services to the most vulnerable people who are permanently de-housed. This strategy aims to provide a permanent form of housing, reducing the homelessness population with provincial government funding. Another important aspect of the charter surrounds the reinvestment and refurbishment of social housing, as affordable rental housing is crucial for the viability and stability of Toronto's neighbourhoods, requiring little barrier to entry to Toronto's $440,000+$ rental homes (Toronto Housing Charter - Opportunity for All, 2017). 


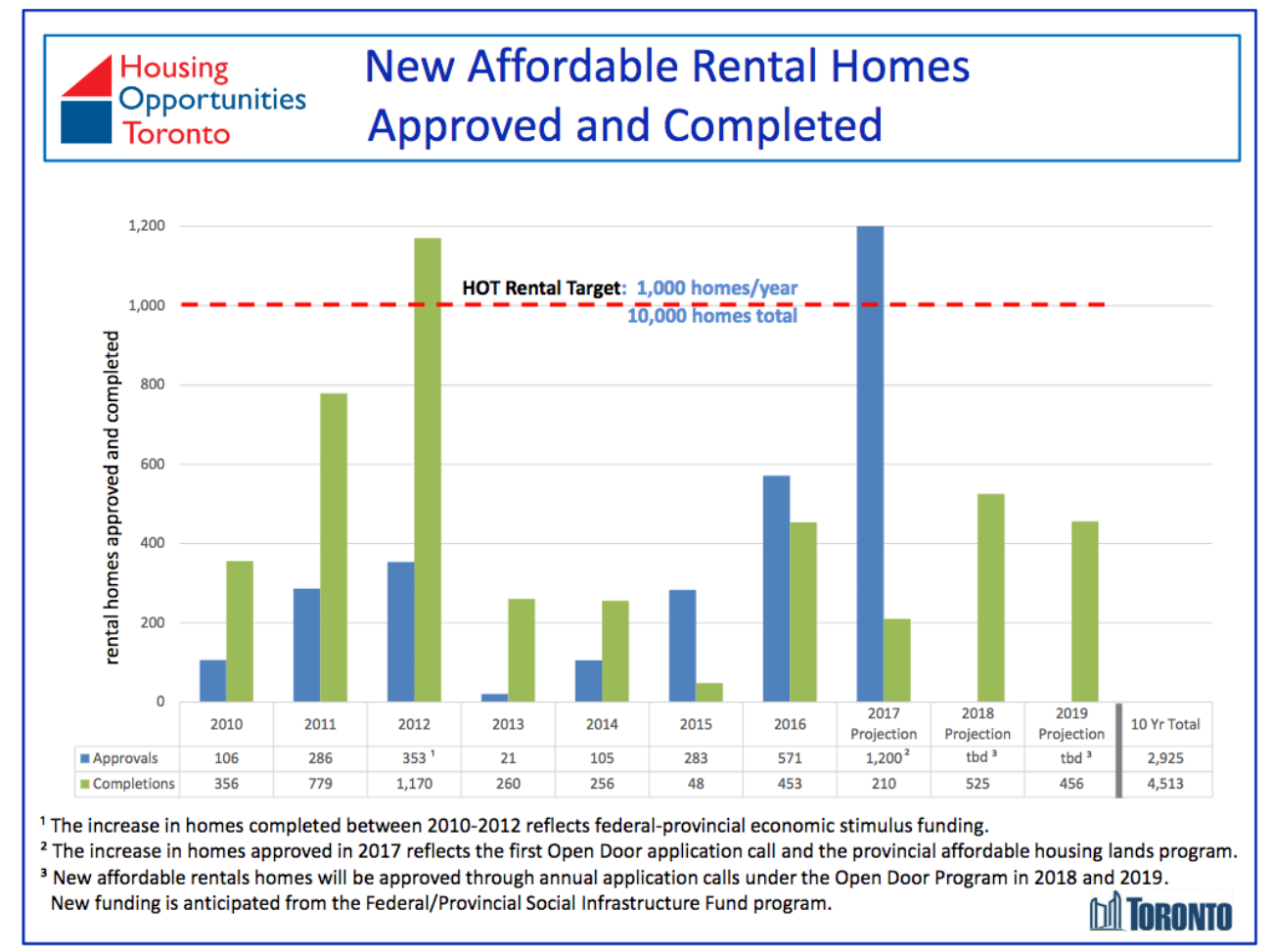

Figure 1 - HOT Action Plan: New Affordable Rental Homes Approved \& Completed 2016 Source: HOT Action Plan Progress Report, City of Toronto, 2016

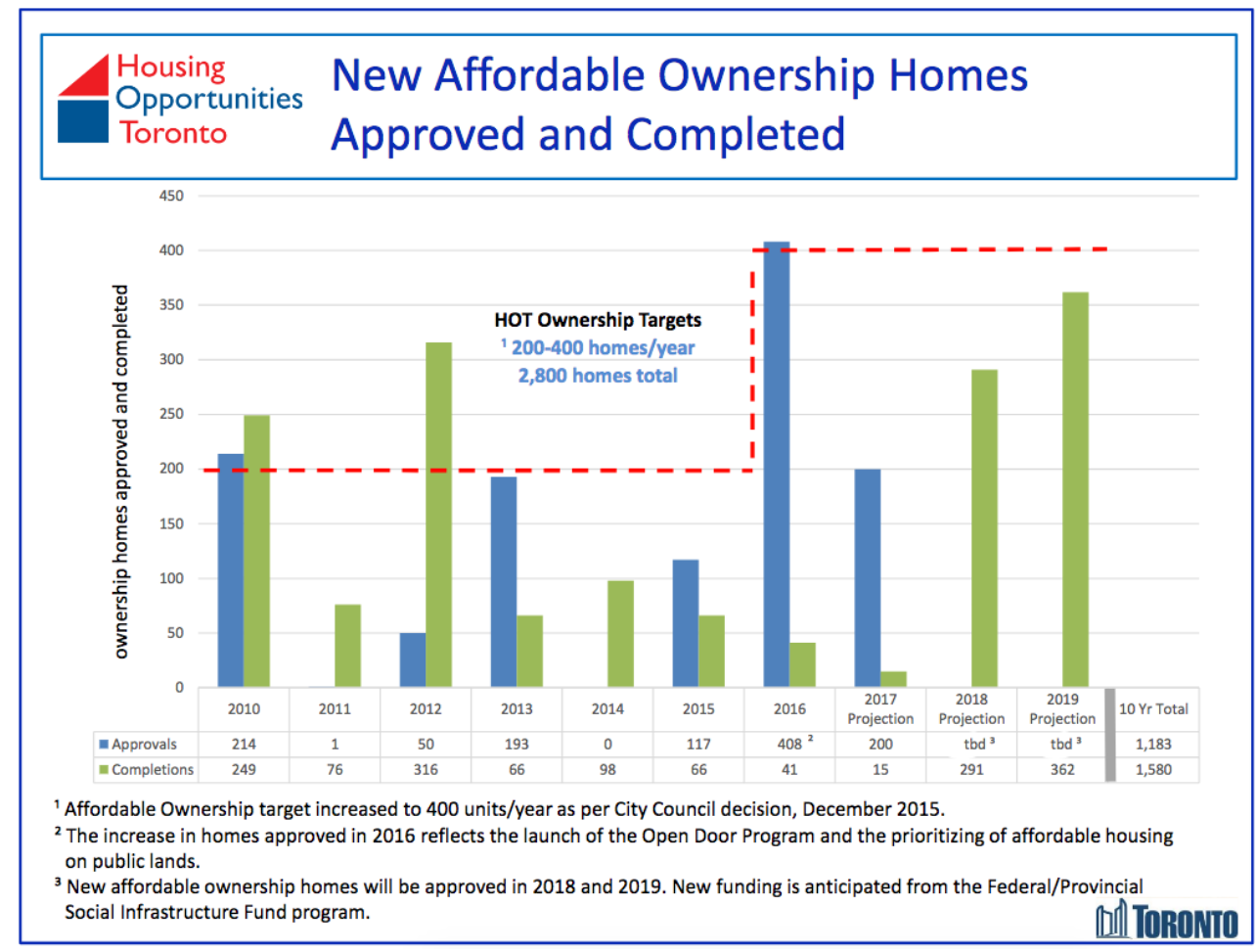

Figure 2 - HOT Action Plan: New Affordable Ownership Homes Approved \& Completed 2016 Source: HOT Action Plan Progress Report, City of Toronto, 2016 


\subsubsection{Municipal - Open Door Policy \& DC Rebate Program}

The City of Toronto has recently started to encourage private (and non-profit) developers to increase the construction of affordable housing with the introduction of the Open Door Program in April 2015. Approved by City Council in 2016, the program includes municipal tax breaks for developers, "fast-tracking" the approvals process, and activating surplus public land. Standing concurrently with the aforementioned HOT Action Plan, the objective of the program is to create 1,000 affordable rental units annually. The program outlines a set of guidelines, including a minimum requirement of twenty percent (20\%) gross floor area of the development towards affordable housing and a minimum of twenty-five (25) years of affordability. The program will largely be funded by a Development Charges Reserve Fund, providing $\$ 10$ million in the year 2017 (Open Door Affordable Housing Program Guidelines, 2018).

The origins of the program were created in response to rapidly increasing housing prices in the Greater Toronto Area. Specifically, the program was created to address housing affordability concerns from the National Housing Strategy, updated stress testing / risk scenarios from Canada Mortgage and Housing Corporation, and the increased demand of the private ownership market (CMHC, 2018). Essentially, these factors have lead Toronto to be engulfed in an unpredictable housing market where home ownership is unaffordable for much of the population. In turn, the solution is thought to be the provision of affordable housing, with residential developers becoming eligible for the program with: Average Market Rents (AMR) at a maximum of $100 \%$ per unit type (see Table 1), a minimum of twenty-five (25) years of affordability period, and a minimum of $20 \%$ of the project's GFA comprising of affordable rental housing.

\section{Table 1 - Toronto's Average Market Rent by Unit Type Source: CMHC, 2018}

\begin{tabular}{|c|c|c|}
\hline Unit Type & AMR & Utility Allowance \\
\hline Bachelor & $\$ 1,019$ & $\$ 85$ \\
\hline
\end{tabular}




\begin{tabular}{|c|c|c|}
\hline 1-Bedroom & $\$ 1,202$ & $\$ 85$ \\
\hline 2-Bedroom & $\$ 1,426$ & $\$ 119$ \\
\hline 3-Bedroom & $\$ 1,595$ & $\$ 139$ \\
\hline
\end{tabular}

The process is initiated and governed by the Request for Proposals, where applicants are required to provide a capital budget for the project, public consultation strategy, an operating expenditures budget, and proposed rents calculations, among many other requirements. In between these submission requirements, there is the evaluation of eight (8) different criteria of one hundred (100) available points, including: affordability details, development and management qualifications, corporate financial viability, project design, capital funding and financing plan, operating and management plan, and development schedule (Applying for Open Door, 2018). This process is admittedly arbitrary, but the city maintains the conception of the Open Door program's ability to help affordable development applications succeed, with one in three applications in 2017 succeeding through the program, all unanimously approved by City Council (Open Door Information Session, 2018).

While the Open Door Program has merit in producing affordable rental housing, its financing structure is inherently complicated. For starters, the Development Charge rebate program is essentially separate from Open Door's various financial benefits such as exemptions from planning application fees, building permit fees, parkland dedication fees, and residential property taxes. These types of fee waivers have up to $\$ 10$ million of capital funding from the city, while the Provincial Development Charges Rebate Program has \$125 million of funding available (provincewide) over five (5) years. The funding from the province for the amount of $\$ 125$ million may seem like a significant amount of subsidy until the draft 2018 Development Charges Bylaw is thoroughly examined, as over the duration of five (5) years, the DC Rebate Program may be able to subsidize five projects at best (Development Charges Bylaw Review, 2018). In short, while the applications appear to be performing and functioning as one, they are essentially separate programs. 
However, an applicant is prioritized for the Development Charges Rebate Program if they initially apply for Open Door, so the applications essentially run concurrently with each other (Open Door Information Session, 2018). The program has produced success stories in the first several years (see Table 2), but the future success of the program remains to be seen on the funding capabilities from both the Federal and Provincial governments.

Table 2 - 2017 Open Door Program Approvals

Source: Results of the 2017 Open Door Call for Applications, September 2017

\begin{tabular}{|c|c|c|c|c|}
\hline $\begin{array}{l}\text { Municipal } \\
\text { Address }\end{array}$ & $\begin{array}{l}\text { Total \& Unit } \\
\text { Mix }\end{array}$ & $\begin{array}{l}\text { Affordability } \\
\text { Period }\end{array}$ & $\begin{array}{l}\text { Application } \\
\text { Type \& Status }\end{array}$ & $\begin{array}{l}\text { Estimated } \\
\text { Completion } \\
\text { Date }\end{array}$ \\
\hline $\begin{array}{l}5365 \text { Dundas St } \\
\text { W., Etobicoke }\end{array}$ & $\begin{array}{l}50 \text { Total } \\
40 \times 2 \text {-Bedroom } \\
10 \times 3 \text {-Bedroom }\end{array}$ & 25 & $\begin{array}{l}\text { Nov-09-2017: } \\
\text { Rezoning \& Site } \\
\text { Plan Approval } \\
\text { (Under Review) }\end{array}$ & June 2021 \\
\hline $\begin{array}{l}2140 \text { Bloor St. } \\
\text { W., Toronto }\end{array}$ & $\begin{array}{l}13 \text { Total } \\
13 \times \text { Bachelors }\end{array}$ & 40 & $\begin{array}{l}\text { Cof A (No } \\
\text { Application) }\end{array}$ & June 2019 \\
\hline $\begin{array}{l}25 \text { Leonard } \\
\text { Ave., Toronto }\end{array}$ & $\begin{array}{l}22 \text { Total } \\
22 \times \text { Bachelors }\end{array}$ & 50 & $\begin{array}{l}\text { Feb-01-2017: } \\
\text { OPA \& } \\
\text { Rezoning } \\
\text { (Approved) }\end{array}$ & June 2018 \\
\hline $\begin{array}{l}30 \text { Cosburn } \\
\text { Ave., Toronto }\end{array}$ & $\begin{array}{l}6 \text { Total } \\
2 \times \text { Bachelor } \\
4 \times 1 \text {-Bedroom }\end{array}$ & 25 & $\begin{array}{l}\text { Nov-19-2014: } \\
\text { Site Plan } \\
\text { Approval } \\
\text { (Approved) }\end{array}$ & December 2018 \\
\hline $\begin{array}{l}136 \text { Kingston } \\
\text { Road, Toronto }\end{array}$ & $\begin{array}{l}24 \text { Total } \\
16 \times 1 \text {-Bedroom } \\
8 \times 2 \text {-Bedroom }\end{array}$ & 25 & $\begin{array}{l}\text { Rezoning \& Site } \\
\text { Plan Approval } \\
\text { (No Application) }\end{array}$ & October 2020 \\
\hline $\begin{array}{l}\text { 355-363 Coxwell } \\
\text { Ave., Toronto }\end{array}$ & $\begin{array}{l}33 \text { Total } \\
7 \times \text { Bachelor } \\
21 \times 1 \text {-Bedroom } \\
5 \times 2 \text {-Bedroom }\end{array}$ & 50 & $\begin{array}{l}\text { July-28-2016: } \\
\text { Rezoning \& Site } \\
\text { Plan Approval } \\
\text { (Approved) }\end{array}$ & May 2019 \\
\hline $\begin{array}{l}1744 \text { Ellesmere } \\
\text { Rd., Toronto }\end{array}$ & $\begin{array}{l}150 \text { Total } \\
27 \times \text { Bachelor } \\
39 \times 1 \text {-Bedroom } \\
52 \times 2 \text {-Bedroom } \\
32 \times 3 \text {-Bedroom }\end{array}$ & 25 & $\begin{array}{l}\text { May-26-2017: } \\
\text { Site Plan } \\
\text { Approval (Under } \\
\text { Review }\end{array}$ & January 2020 \\
\hline
\end{tabular}

\subsection{Inclusionary Zoning}

2.3.1 Inclusionary Zoning Policy Timeline in Ontario since the 1990's

1991 - 1993: The former City of Toronto commissions an Inclusionary Zoning study in conjunction with the Ontario Ministry of Housing 
Impact: The study documented many potential difficulties implementing inclusionary zoning, including: the provision of off-site units, qualifications of potential purchases, and the unit sizes and mix (City of Toronto Housing Department, 1991).

April 15 , 1999: The Mayor's Homelessness Action Task Force Final Report: Recommendations and Policy Directions related to the Housing Policies of the Official Plan

Impact: Recommendation 93 proposes for City Council to request amendments to the City of Toronto Act to require the inclusion of affordable housing in new residential developments, citing case studies in the United States and British Columbia (Commissioner of the Urban Planning and Development Services, 1999).

January $31^{\text {st }}$, 2006: The Proposed Growth Plan for the Greater Golden Horseshoe

Impact: Section (3) (f) recommends that the Minister modify the proposed Growth Plan to: "reiterate previous requests that the minister co-ordinate with other ministries to facilitate the Plan's effective implementation, including inclusionary zoning powers to ensure that affordable housing may be included in residential or mixed-use developments" (The Proposed Growth Plan for the GGH, 2006). The Growth Plan dictates where and how to grow and the city released its first modern intentions to align with provincial policy guidelines and implement strategies to enact mandatory inclusionary zoning.

June 10 $0^{\text {th }}$, 2015: Proposed Amendments Introduced Through Bill 73, Smart Growth for Our Communities Act, 2015

Impact: On December $3^{\text {rd }}$, 2015, Bill 73, Smart Growth for Our Communities Act received Royal Assent, updating the Planning Act and the Development Charges Act. In June of 2015, the City of Toronto's Planning \& Growth Management Committee recommended City to Council to request 
to the Minister of Municipal Affairs and Housing to allow municipalities to ratify the provision of inclusionary housing powers that are "distinct from Section 37 of the Planning Act" (Planning \& Growth Management Committee, 2015).

December 8th, 2016, Bill 7: The Promoting Affordable Housing Act, was given royal assent

Impact: This Bill introduced the first significant framework for municipalities to enact inclusionary zoning provisions in Ontario (Promoting Affordable Housing Act, 2016).

December $18^{\text {th }}$, 2017: The Province of Ontario releases summary of its proposed Inclusionary Zoning regulations

Impact: After years of consultation between the Province and Municipalities (Inclusionary Zoning Consultation Discussion Guide, 2016), the Province of Ontario announces the proposed regulatory content of inclusionary zoning, finally released a set of quantitative requirements of the new policies.

January 24 ${ }^{\text {th }}$, 2018: Bill 7 - Response to the Proposed Inclusionary Zoning Regulation

Impact: Toronto City Planning releases staff report recommending changes to the Planning \& Growth Management Committee regarding the Province's proposed inclusionary zoning regulations, roughly concluding that the regulations fall short of municipal plans concerning the provision of affordable housing. Specifically, the staff report is critical of the "overly prescriptive framework" that restricts local policy adjustments to better suit the needs of each community i.e. ownership units and a maximum percentage of affordable units that can be secured (Planning \& Growth Management Committee, 2018). 


\subsubsection{Summary of Ontario's Proposed Inclusionary Zoning Regulations}

The aforementioned policy timeline provided a framework of inclusionary housing policies in Ontario and Toronto - outlining the progress of how increasing the provision of affordable housing in Toronto can be achieved. While subject to (extremely probable) modifications, the proposed regulations can be conceptualized in the following four different categories, addressing many aspects of municipal implementation (Peter Milczyn, 2018). Please note that these proposed requirements exclusively apply to home ownership, rather than rental homes.

\section{Unit Number Activation}

While municipalities will be able to determine which areas inclusionary zoning regulations are to be compulsory through Official Plans and Zoning By-laws, only new residential developments which have twenty (20) or more units will be eligible to fulfill the new inclusionary zoning requirements.

\section{Percentage of Units \& Location}

The new regulations propose that municipalities will be able to enforce either a maximum of five percent $(5 \%)$ or ten percent $(10 \%)$ of a new development to include affordable housing, contingent on whether the development is located in an area designated as "High Density Transit-Station" area, as recognized by the Official Plan. Specifically, a zoning by-law will enforce that residential developments on lands designed as High Density Transit-Station areas will require a maximum of $10 \%$ of residential net saleable area (NSA) to include affordable housing, while all other lands can require a maximum of $5 \%$ of residential NSA. Net Saleable area is very granular in its definition, but is typically defined as floor area that can be sold, thus excluding common spaces, balconies, patios, etc. 
While having off-site units can be inherently problematic (Thaden and Wang, 2017), the proposed regulations include many restrictions on the provision of off-site units, including if:

- the off-site units are in close proximity to the residential development;

- the off-site units are located on lands zoned for inclusionary zoning;

- the off-site units are equipped for occupancy for a maximum of thirty-six (36) months after the transfer of units from the residential development;

- the off-site units will not count towards fulfilling the existing inclusionary zoning requirements to which the lands would otherwise be subject to; and

- there is a maximum of fifty percent (50\%) of affordable units in the off-site development thus preventing a potentially segregated, affordable residential building.

\section{Incentives \& Section 37}

The regulations require a municipality analogous to Toronto (i.e. no Community Planning Permit System) to be required to provide a variety of incentives to offset forty percent (40\%) of lost revenue due the reduced prices of the affordable units. The calculation of lost revenue is to be defined by formulas outlined in the Official Plan and Zoning By-law.

In terms of Section 37, the province's proposed regulations outline that the added height and density from the provision of affordable units cannot be used to arbitrate the Section 37 benefits paid by the developer. Conversely, municipalities will noticeably also be prohibited from receiving additional Section 37 benefits from the developer from the result of the added height and density from the provision of affordable units.

\subsection{Literature Review}


The literature explored below reflects the most recent documents that are most relevant to currently policy in the context of the Province of Ontario. By no means does this include all works related to the history of the introduction and enactment of inclusionary zoning policies throughout the world, dating back to the 1970's in Washington D.C. and San Francisco (Thaden and Wang (2017). The following studies extensively outline the statistics and program characteristics of existing and in-force inclusionary zoning policies, allowing trends and program characteristics to be used for the purposes of the pro forma analysis and alternative approaches.

\subsubsection{Urban Land Institute: The Economics of Inclusionary Development, 2016}

In The Economics of Inclusionary Development, Williams et al. (2016) note that in the United States, at least twenty-five percent of rents, and sixteen percent of homeowners pay at least half of their income towards housing. As seen in Figure 3, juxtaposed with 2017 trends in Toronto, a family with a median household income would have to contribute upwards of $70 \%$ towards ownership costs (RBC, 2017). Canada's Mortgage and Housing Corporation (CMHC) defines affordable housing as shelter costs including utilities accounting for less than 30 per cent of before-tax household income (CMHC, 2017). This metric of affordability is remarkably concerning for Toronto, with the spike in all forms of housing prices from 2015 to 2017. 


\section{Toronto Area}

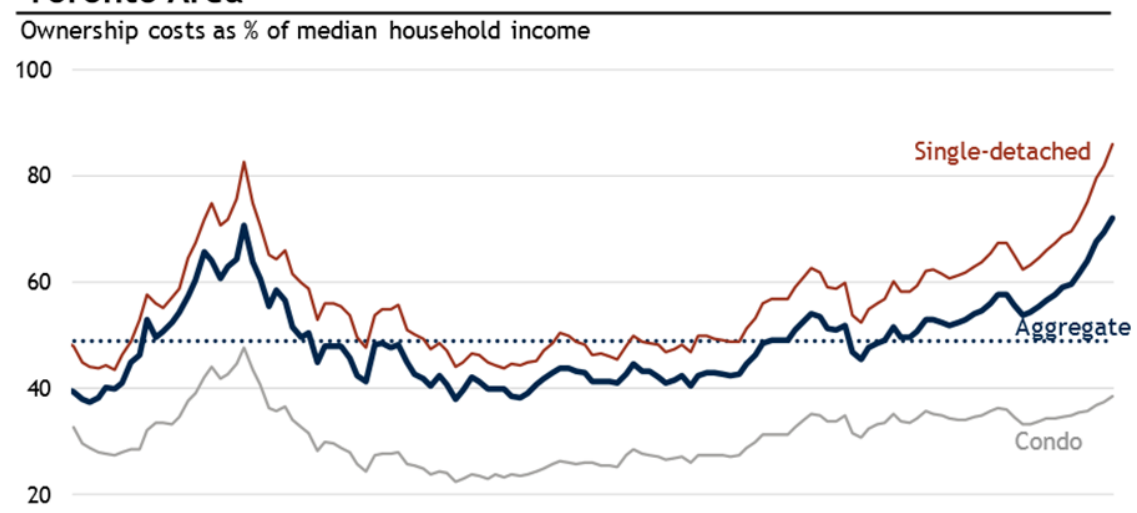

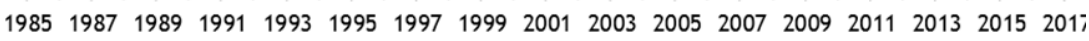

Figure 3 - Toronto Home Ownership Costs as \% of Median Household Income Source: Housing Trends and Affordability, RBC (June 2017)

Williams et al. (2016) provide an inquiry that can be applied to future Inclusionary Zoning implementation in Toronto, as they wonder how can an Inclusionary Zoning policy be best designed to work in the context of the local real estate development market (Williams et al., 2016). Interestingly, they focus solely on multi-family rental development. In other words, affordable ownership will not be considered, nor will single-detached forms of housing. The authors state four notable conclusions surrounding the economics of Inclusionary Zoning. First, cities are relying on local zoning authorities to generate housing through Inclusionary Zoning. While the study does originate from a United States-based context, this notion is similar in Toronto, with the municipalities acting as creatures of the province of Ontario. As previously mentioned, Bill 7 allows for municipalities to create a framework for Inclusionary Zoning in Toronto, which must be included in municipal official plan policies.

Next, the authors note that the goal of inclusionary zoning is to create below-market rental apartments. This notion is applicable in the Toronto context, with the province's goals increasing the supply of affordable units. Specifically, this conclusion aligns with the legislation noting that 
municipalities cannot accept cash-in-lieu of affordable units. The goal is explicitly to create affordable units for low-income individuals to utilize a soon as possible, and cash-in-lieu is inherently convoluted, from the lack of clarity surrounding the uses of funds.

The third key conclusion that the authors note is that jurisdictions must provide development incentives - density bonuses, subsidies, tax waivers, and/or less required provision of parking. This uniquely aligns with Section 37 of the Planning Act in the City of Toronto, which allows for increased building height and density in exchange for community benefits. While inclusionary zoning is not yet in the process of municipal implementation, there is potential for an immediate impact with the Planning Act having existing policies permitting a public-private exchange.

Lastly, the authors conclude that in an ideal world, Inclusionary Zoning creates units that otherwise would not have been built. Fascinatingly, this could be the most controversial and subjective aspect of inclusionary zoning, with private developers often arguing that these types of housing control measures have the potential to increase the cost of market-priced units, while restricting the number of units being developed as a whole. A Fall 2017 manuscript comes from Ben Myers, the Senior Vice President of Market Research and Analytics for Fortress Real Developments, a multi-billion-dollar Canadian residential developer with 20 projects currently under construction. In his Market Manuscript - Analysis of the Canadian Residential Housing Market, he takes an in-depth look at Ontario's Fair Housing Plan, interviews with urban planners in Ontario, and other quantitative housing data for major metropolitan areas in Canada. He concludes that housing supply must keep pace with housing demand, which is increasingly difficult with restrictive zoning practices (Myers, 2017). 
The document by Williams et al. is remarkably relevant in the context of Toronto because they can adequately explain the two key economic indicators of below-market unit provisions. The setaside percentage is important to understand when considering the provision of Inclusionary Zoning because it significantly impacts the financial feasibility of the project. In other words, the difference between setting aside ten percent or twenty percent of units for below-market cost would significantly impact the residual land values of any project. As seen in Table 1, the land value decrease with a $10 \%$ set-aside amounts to a larger decrease in land value in Area B, a scenario with a higher percentage. The other key economic indicator is the average median income (AMI). Popular Inclusionary Zoning policies in the United States often employ different requirements of different AMI targets, resulting in a differing residual land values. The authors state that the difference in affordability dramatically affects the feasibility of the development. Specifically, they cite a similar scenario to Table 1, with an $80 \%$ AMI requirement resulting in a residual land value of $\$ 223$ per $\mathrm{ft}^{2}$, and a $60 \% \mathrm{AMI}$ requirement resulting in a residual land value of $\$ 210$ per $\mathrm{ft}^{2}$. In Toronto, there is a gap in research when studying these key economic indicators in significant intersections accommodating different rents (Williams et. al, 2017).

Table 3 - Land Residual of a Development at Different Set-aside Levels (5-storey, 177-units) Source: Urban Land Institute (2017)

\begin{tabular}{|c|c|c|c|}
\hline \multicolumn{2}{|c|}{ Area A - achievable rent of $\$ 3.00 / \mathrm{ft}^{2}$} & \multicolumn{2}{c|}{ Area B - achievable rent of $\$ 3.50 / \mathrm{ft}^{2}$} \\
\hline Set-aside Percentage & Outcome & Set-aside Percentage & Outcome \\
\hline $0 \%$ & $\begin{array}{c}\text { Developer can pay } \\
\$ 118 / \mathrm{ft}^{2}\end{array}$ & $0 \%$ & $\begin{array}{c}\text { Developer can pay } \\
\$ 295 / \mathrm{ft}^{2}\end{array}$ \\
\hline $10 \%$ & $\begin{array}{c}\text { Developer can pay } \\
\$ 64 / \mathrm{ft}^{2}\end{array}$ & $10 \%$ & $\begin{array}{c}\text { Developer can pay } \\
\$ 223 / \mathrm{ft}^{2}\end{array}$ \\
\hline $20 \%$ & $\begin{array}{c}\text { Developer can pay } \\
\$ 10 / \mathrm{ft}^{2}\end{array}$ & $20 \%$ & $\begin{array}{c}\text { Developer can pay } \\
\$ 150 / \mathrm{ft}^{2}\end{array}$ \\
\hline
\end{tabular}

2.4.2 Lincoln Land Institute: Inclusionary Housing in the United States: Prevalence, Impact, and Practices, September 2017

The second applicable quantitative-based pieces of literature on Inclusionary Zoning come from Thaden and Wang (2017) from the Lincoln Land Institute. Titled Inclusionary Housing in the 
United States: Prevalence, Impact, and Practices, the document is a remarkably comprehensive and up-to-date study of the presence and effectiveness of Inclusionary Zoning 886 jurisdictions in all 25 states that employ Inclusionary Zoning policies or guidelines.

Out of all the programs that the authors surveys, they noted many interesting conclusions that could be applied in the context of Toronto. In terms of the geographic area, the authors found that $71 \%$ of Inclusionary Zoning programs applied to the entire jurisdiction, while only $22 \%$ applied to certain zones, neighborhoods, or districts. As seen in Table 4, a recent Toronto Star exposé detailed different intersections in Toronto, noting vividly different condominium prices in twentyfive separate locations in Midtown, Downtown, Financial District, Entertainment District. Effective Inclusionary Zoning policy implementation has the potential to exist in Toronto with distinct applications in certain intersections. As previously mentioned, the ULI document details effective Inclusionary Zoning practices that exist on a curve, with the y-axis representing the AMI, and the $\mathrm{x}$-axis representing the set-aside percentage.

Table 4 - Condominium Prices in Toronto's Key Intersections Source: Altus Group, 2018

\begin{tabular}{|c|c|c|}
\hline Intersection & Average Price 1 Bedroom & Average Price 2 Bedroom \\
\hline King and Bathurst & $\$ 533,162$ & $\$ 986,873$ \\
\hline King and Spadina & $\$ 540,153$ & $\$ 860,149$ \\
\hline King and Yonge & $\$ 491,203$ & $\$ 962,182$ \\
\hline Avenue and Bloor & $\$ 783,785$ & $\$ 1,346.615$ \\
\hline Yonge and St. Clair & $\$ 471,380$ & $\$ 882,006$ \\
\hline Yonge and Eglinton & $\$ 507,899$ & $\$ 735,771$ \\
\hline
\end{tabular}

The next program characteristic Thaden and Wang (2017) investigate is policy type, with the most common policies comprising of mandatory for-sale development, and mandatory rental development, making up 54\% and $42 \%$ of Inclusionary Zoning programs in The United States. The authors later confirm that mandatory programs do in fact make more contributions to affordable housing than their voluntary counterparts, with added benefits of having more options 
to contribute - on-site affordable units, in-lieu fees, off-site affordable units, land donations, or preserving / rehabbing social housing.

The final notable program characteristic the authors observe surround the aforementioned metrics of $\mathrm{AMI}$ and set-aside percentage. $27 \%$ of Inclusionary Zoning programs surveyed stated a $1 \%$ to $10 \%$ set-aside percentage, while $36 \%$ of respondents noted an $11 \%$ to $20 \%$ set-aside percentage. In regard to $\mathrm{AMI}, 42 \%$ of US Inclusionary Zoning programs recorded multiple AMI tiers served, implying a flexibility in implementation. This has the potential to be effective in Toronto, having a mandatory set-aside percentage in the city, but with different AMI tiers in various intersections throughout the city, due to the inherent variety of income levels throughout each neighbourhood.

Both ULI and Lincoln Land Institute documents outline a significant amount of different policy characteristics and feasibility metrics that can be employed and well-utilized in Toronto. Although voluntary programs can offer more incentives to developers, mandatory programs are more common and produce more affordable units (Thaden and Wang, 2017). A 2004 American Planning Association also confirms this notion, stating that mandatory Inclusionary Zoning ordinances are most effective when implemented properly (Brunick, 2004). Although these studies exclusively focus on jurisdictions in the United States, they offer useful insights on the potential of an implementation on a Toronto-housing market, often with similar levels of population, housing starts, and demographics (City Data, 2017). Enforcing a mandatory set-aside percentage with a high number of options with program characteristics in geographic application, incentives, or contribution options have the potential to make Inclusionary Zoning viable in Toronto when looking at economic feasibility. Additionally, each document notes that while the construction and development of affordable housing is important for a variety of social, environmental, and economic reasons, the commitment to rental units lasting beyond thirty years 
is crucial to maintaining quantifiable progress, as is confirmed by $90 \%$ of respondents confirming this term of affordability over thirty years (Thaden and Wang, 2017).

\subsubsection{Lincoln Institute of Land Policy: Land Value Capture \& Inclusionary Zoning (August- 2017)}

This document comprehensively outlines the impacts of various affordable housing and inclusionary zoning programs in: Cambridge (MA), Denver (CO), Pasadena (CA), Portland (OR), Seattle (WA), and San Jose (CA). Prototypes of multiple development projects are modelled, reflecting and projecting future market conditions with certain inclusionary programs implemented. Inclusionary zoning programs are then evaluated by comparing variables with and without the program. The authors (David Paul Rosen \& Associates, 2017) detail the long list of issues associated with the delivery of affordable housing, including issues surrounding timing, resale restrictions, partial units, and geographic applicability. Many of these concepts are incorporated in the below methods section of this document.

\subsubsection{Inclusionary Zoning in International Perspective (Mallach and Calavita, 2010)}

Summarizing affordable housing and inclusionary zoning programs and policies throughout the world, Alan Mallach and Nico Calavita examine Canada in Chapter three, noting that although Canada's inclusionary zoning polices are heavily influenced by the United States, they are administered differently due to the increased role of provinces versus states (Mallach and Calavita, 2010).

Mallack and Calavita examine the origin of inclusionary zoning policies in Canada, noting that the planning framework offers minimal support for this form of land value recapturing. As follows, 
inclusionary zoning is a relatively new policy concept in Canada, with British Columbia being the first province to authorize municipalities to enact inclusionary zoning policies in 1999, under section 904 of the Local Government Act. British Columbia was the first province to study and note the benefits of mixed income affordable housing models, allowing low-income residents to avoid isolation and the concentration of poverty (Mallach and Calavita, 2010).

The authors presented Montreal, Quebec as another pertinent case study, with the municipal enactment of a voluntary inclusionary zoning program in 2007. Interestingly, Mallach and Calavita note that while the city's thirty percent $(30 \%)$ set-aside amount was only a goal, the program produced excess of the intended target over the first two years of the program leveraging the capacity of a strong non-profit sector. In summary, the authors provide a description of a functional inclusionary zoning program that is voluntary and flexible, which can be a solution for ineffective policy implementation (Mallach and Calavita, 2010). 


\subsection{METHOD}

\subsection{Methods and Target Introduction}

Broadly stated, the intention of this document is to accurately measure the impact of the proposed inclusionary zoning policies on specific geographic areas in Toronto, assuming all other variables are similar in terms of unit mix, density, construction costs, etc. As per the proposed guidelines from the province, the analysis only includes the provision of ownership units, accounting for this sector of the private market.

Inclusionary zoning could have a much larger impact than initially anticipated, and this analysis is determining its impact on the variables of land prices and revenue. The goal is to narrow down one factor for each of the development budget and revenue portions of development financial feasibility. In an ideal world, development would still be feasible, while major aspects of the projects would have the ability to be altered. The worst-case scenario and conclusion of the implementation of inclusionary zoning would result in a stand-still for the private development industry - resulting in the inability to build new units. Feasibility is not determinate on one specific factor, as it varies on the threshold, time period, market area, etc. The goal of this work aims to narrow down and identify two key price-related variables that could be directly impacted with the province allowing municipalities to enact new housing restrictions \& regulations.

\section{$\underline{3.2 \text { Study Areas }}$}

The proposed inclusionary zoning regulations under the Promoting Affordable Housing Act, 2016 outline a maximum set-aside of ten percent (10\%) of units near high density transit-station areas, 
as identified by the official plan. This can narrow down the geographic area of major intersections to be identified, as this model will select and analyze three (3) different site areas.

The Growth Plan for the Greater Golden Horseshoe outlines and defines major transit station areas as:

"The area including and around any existing or planned higher order transit station or stop within a settlement area; or the area including and around a major bus depot in an urban core. Major transit station areas generally are defined as the area within an approximate 500 metre radius of a transit station, representing about a 10-minute walk" (Places to Grow, 2017).

This definition will shape the proposed inclusionary zoning regulation's definition of high density transit-station areas, as the municipality enacting new policies within its Official Plan will conform with the definition, as outlined by the province. Reviewing all land transactions within a five hundred metre $(500 \mathrm{~m})$ radius would provide a sufficient amount of data plus the ability to thoroughly look at average land prices per annum.

\subsubsection{King Street West \& Spadina Avenue}

Also known as the "Entertainment District," the intersection of King and Spadina is home to one of Toronto's densest residential high-rise neighbourhoods, with the population expecting to double to over 40,000 residents by 2020 (King Spadina Secondary Plan, 2017). Although not directly within $500 \mathrm{~m}$ of higher order transit, it is a mere 1.0 kilometre from union station, the busiest transportation hub in Canada (GO Transit, 2016). The area is rapidly growing, and as seen in Figure 5, the area is trying to balance heritage values with a new residents and infrastructure. Figure 4 displays the identified land purchases, providing data that will be incorporated to the residual land value analysis (Altus, 2018). 

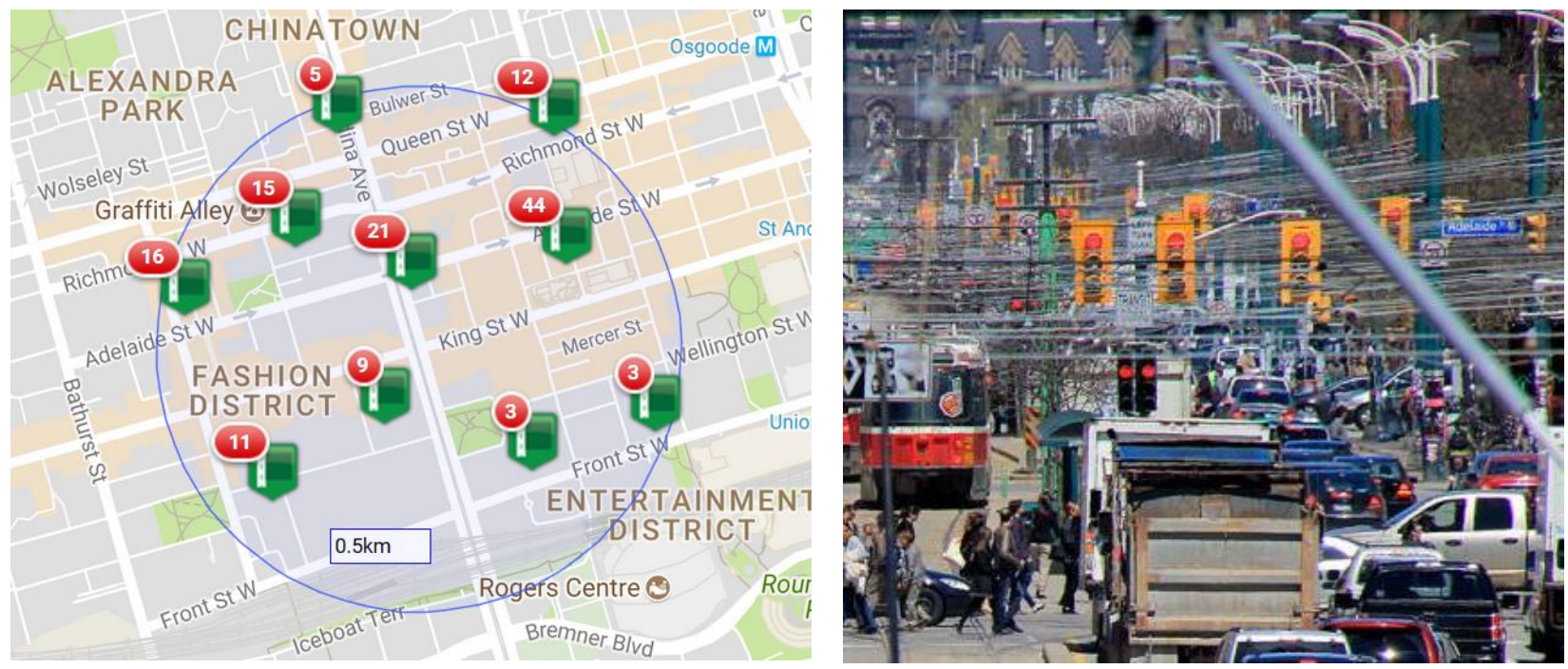

Figure 4 - Land Purchases within 500m of the Intersection of King Street West \& Spadina Avenue Source: Altus Group, 2018

Figure 5 - Spadina Avenue Looking North, Source: Urban Toronto, 2017

\subsubsection{Yonge Street and Eglinton Avenue (East \& West)}

Located in midtown Toronto, the intersection of Yonge Street and Eglinton Avenue (East and West) has been the centre of rapid development over the last decade (as seen in residential land purchases in Figure 6), adding a significant number of individuals who live and work in the area. This has lead city planning staff to the creation of Midtown in Focus, a Secondary Plan guiding how growth should function in terms of built form, land use, and specific character areas (Midtown in Focus, 2017). This high growth area was selected for the purposes of this study because of the capital investment into transit infrastructure in the form of Metrolinx's Eglinton Crosstown LRT, in addition to the existing Yonge-University Line Subway Station. The anticipated new transit addition to the area will supplement the increasingly growing population, and it will be fascinating to examine how the implementation of inclusionary zoning policies would function in this rapidly growing area. 

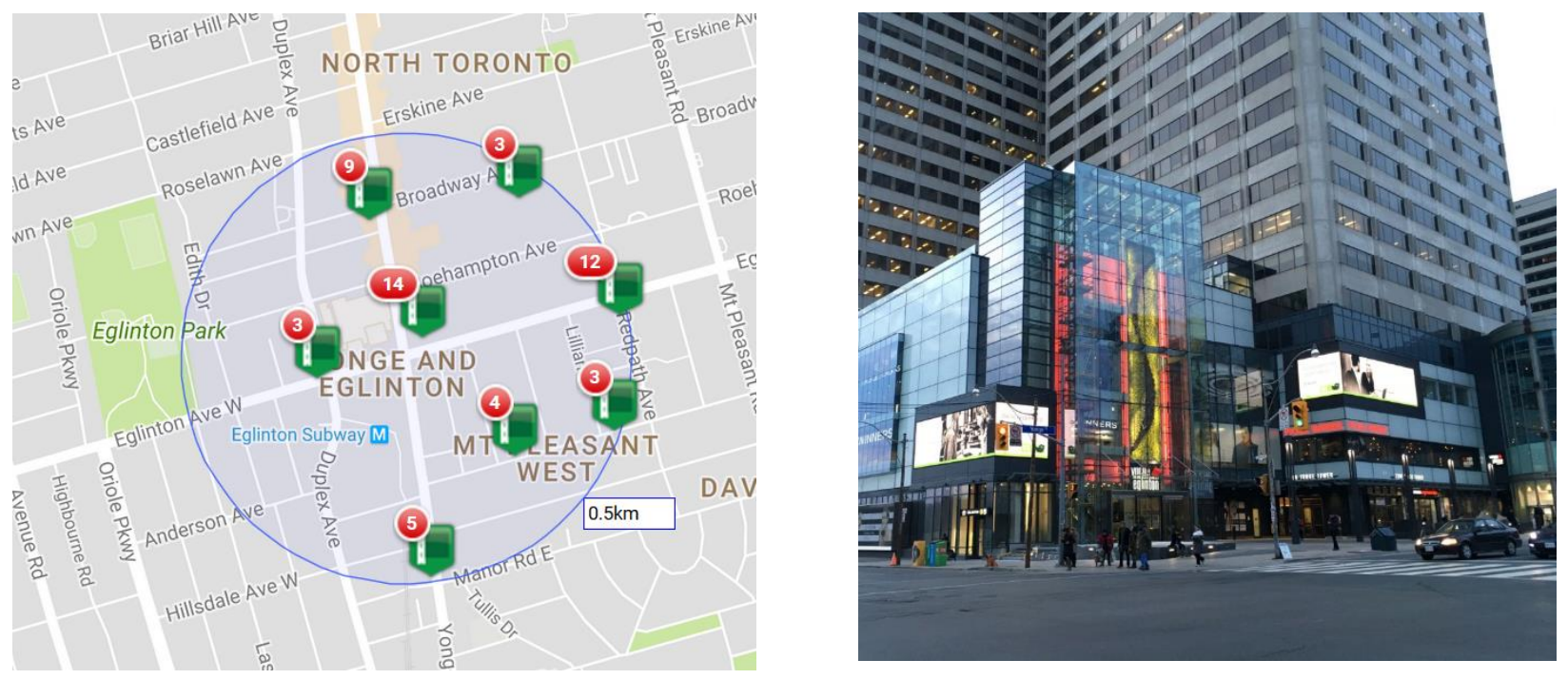

Figure 6 - Land Purchases within 500m the Intersection of Yonge Street \& Eglinton Avenue Source: Altus Group, 2018

Figure 7 - RioCan's Yonge Eglin Centre Redevelopment, Source: Toronto Star, 2016

\subsubsection{Bloor Street West and Dundas Street West}

Located in and around the Bloor Subway (Line 2), GO Station, and UP Express, the intersection of Bloor Street West and Dundas Street West is a significant transit hub located in the west end of the City of Toronto. While development is not as prevalent as the aforementioned locations (as displayed in Figure 8), private market interest has increased over the last decade due to large lot sizes and the ability to increase height and density (City of Toronto Development Applications, 2018). This is a key area to target for the implementation of the proposed inclusionary zoning regulations because it is external from the downtown core while still being connected to a major transit hub, both municipally and provincially. The area also contains a 10-acre site owned by Choice Properties REIT, as seen in Figure 9. The site is subject to a major redevelopment, with the opportunity to add thousands of residents and jobs throughout the area, complimenting the proximal transit. 

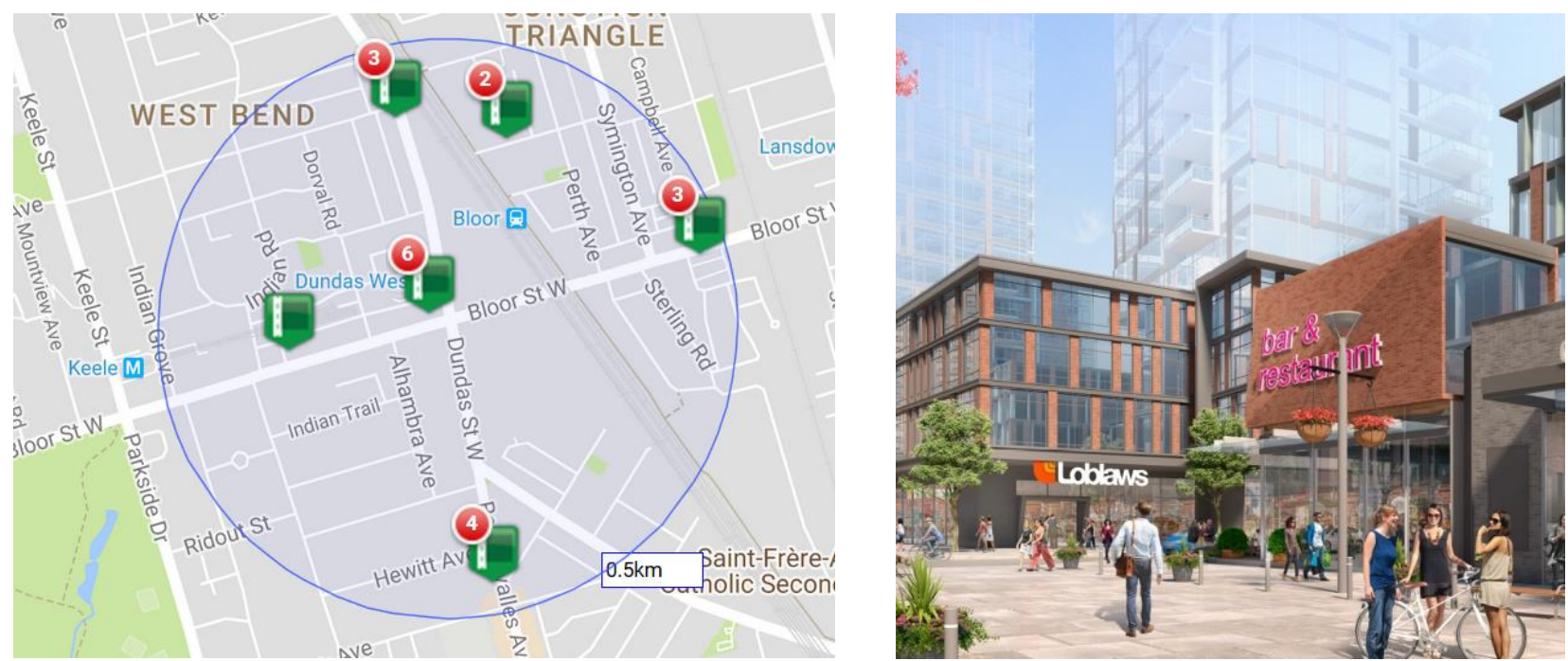

Figure 8 - Land Purchases within 500m the Intersection of Bloor Street W \& Dundas Street W Source: Altus Group, 2018

Figure 9 - A Rendering of Choice Properties' Bloor-Dundas Redevelopment, Source: CBC, 2017

\subsection{Pro Forma Analysis}

A pro forma is a method of financial analysis used to determine the feasibility of a development project by analyzing certain inflows and outflows. For the purposes of this MRP, the base pro forma is separated in four (4) different sections to adequately outline an accurate cost of a high rise mixed-use condominium development. For reference, the pro formas are included in Appendices A, B, and C. Please note all input assumptions are uniform throughout each of the three (3) models, ensuring uniformity for the purposes of comparability and evaluation. The assumptions are broadly based on off-the-record interviews with industry experts, as well as averages complied from Altus \& RealNet, retrieved in March 2018.

\subsubsection{Site Statistics}


The first section outlines assumptions regarding the massing and built form of the project. These assumptions form the granular details about the building, including the division between gross construction area and net salable area, and the size and composition of all units. For reference, the allowable density per the applicable zoning by-law (569-2013, 438-86, etc.) is listed above the proposed density, which is the total gross floor area divided by the site area. An efficiency of $82.5 \%$ is used to calculate net sellable area, which is the square footage of the floor area that can be sold. The net saleable are excludes building elements such as elevators, hallways, stairwells, etc. To reflect the implementation of inclusionary zoning, there is a line item outlining ten percent $(10 \%)$ of the residential net sellable area set aside for inclusionary units, resulting in an updated total of net sellable area of $90 \%$ of the previous value, to avoid circular references. As mentioned in the proposed regulation, inclusionary zoning is not an additional ten percent (10\%) of units, as it must be subtracted from the current amount.

\subsubsection{Development Budget}

The development budget section contains all the costs of the development, including intricacies relating to construction. The first significant cost is the land, which is calculated using the land price multiplied by the buildable gross floor area. The hard costs are taken from the 2018 Altus Cost Guide, including the approximate thirty percent (30\%) costs associated for earth retention for below-grade parking construction. The hard costs encompass all costs associated with the construction of the building including labour, materials, management, etc. The soft costs include all consultants used during the planning and development process - typically during the first three to five (3-5) years. The remainder of the costs associated with development surround the initial sales, marketing and occupancy of the building, including the expenditures accompanying sales commissions, legal fees, closing costs, occupancy operating expenses, etc. 


\subsubsection{Revenue}

The revenue section is where the impact of inclusionary zoning can be directly observed, with a distinctly different line item for the price per sqf for the condos designated for inclusionary zoning by the developer, as per the Official Plan. In the proposed inclusionary zoning guidelines, section

1 (d) notes that the official plan would be required to include provisions for matters that would:

"identify an approach to setting an average market price for each proposed unit type that may be required to be provided as affordable housing units in an inclusionary zoning by-law. The average market price may vary across different locations within the municipality. The average market price would be updated annually." (MAH, 2017)

A crucial portion of the feasibility and impact of inclusionary zoning in Toronto depends on the currently unknown definition of affordable housing. The Provincial Policy Statement defines ownership housing as the least expensive of:

i. "housing for which the purchase price results in annual accommodation costs which do not exceed 30 percent of gross annual household income for low and moderate-income households; or

ii. housing for which the purchase price is at least 10 percent below the average purchase price of a resale unit in the regional market area;" (PPS, 2015).

Whereas the Toronto Official Plan defines affordable ownership as:

"housing which is priced at or below an amount where the total monthly shelter cost (mortgage principal and interest - based on a 25-year amortization, 10 per cent down payment and the chartered bank administered mortgage rate for a conventional 5-year mortgage as reported by the Bank of Canada at the time of application - plus property taxes calculated on a monthly basis) equals the average City of Toronto rent, by unit type, as reported annually by the Canada Mortgage and Housing Corporation. Affordable ownership price includes GST and any other mandatory costs associated with purchasing the unit” (Toronto Official Plan, 2015)

Using aspects from both the provincial and municipal-level definition of affordable home ownership, this study can conservatively incorporate approximate monthly mortgage payments

from Table 1, totalling the following estimates for affordable ownership housing prices, via the 
most recent data from CMHC Rental Market Report, Fall 2017. Incorporating all available price calculations, the pro forma will apply prices from the following Table 5:

Table 5: Updated Affordable Ownership Price / Unit Source: CMHC, 2017

\begin{tabular}{|l|r|r|r|r|}
\hline \multicolumn{5}{|c|}{ Definition of Affordable Ownership / Unit } \\
\hline Unit Type & Bachelor & 1-Bedroom & 2-Bedroom & 3-Bedroom \\
\hline AMR incl. Utility & $\$ 1,104$ & $\$ 1,287$ & $\$ 1,545$ & $\$ 1,734$ \\
\hline Affordable Price & $\$ 220,000$ & $\$ 257,000$ & $\$ 305,000$ & $\$ 345,000$ \\
\hline
\end{tabular}

In summary, the market-rate condo price / sqf totals $\$ 900$, while the inclusionary units total $\$ 533$, when determining the sqf for each unit type multiplied by the number of units. The remainder of the revenue contains proceeds from the sale of the commercial space, residential parking spaces, lockers, etc. Additionally, a key portion of the revenue comprises of the forty percent (40\%) municipal rebate from additional revenue lost from the mandated inclusionary units. The revenue line items sum to the total project revenue, which is used to calculate project returns. Figure 10 simplifies the concept of AMR, providing examples of ordinary occupations in conjunction with specific percentages. 


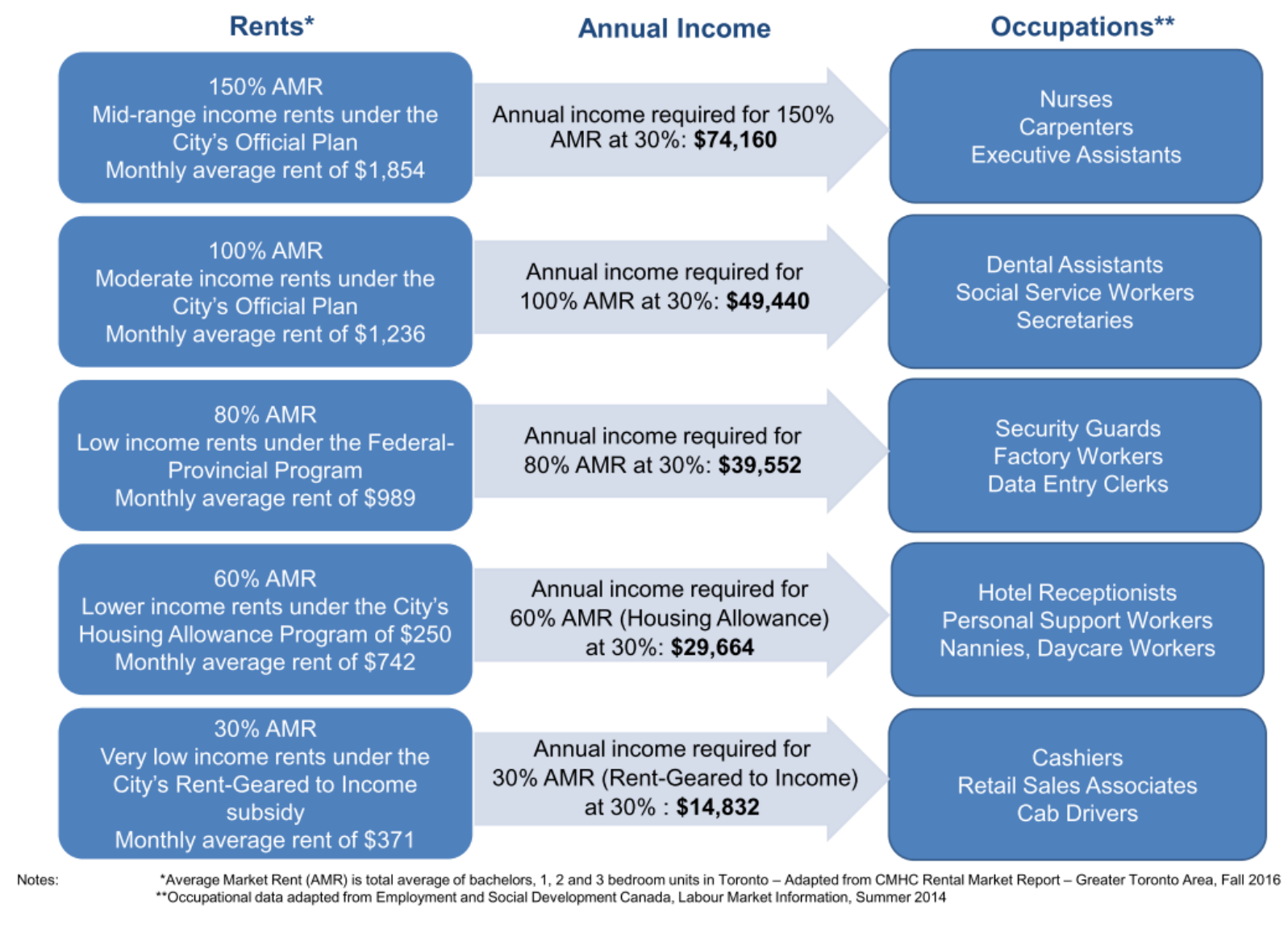

Figure 10 - Toronto Rents and Affordability by Income Band

Source: Affordable Housing Office, 2016

\subsubsection{Project Returns}

The last tab surrounds the evaluation of the project, calculating the project's costs and revenues by the desired rate of return. The total revenue is the sum from the total project revenue tab, while the same applied for the total budget tab, as it is linked directly to total project costs. The total profit is calculated by subtracting the budget from the revenue, resulting in your end profit.

Equity required is determined by a financial institution condition, typically amounting to a fifteen percent (15\%) loan to cost ratio, necessitating that fifteen percent of the project costs are funded by developer equity. The profit from the budget is determined by dividing the total profit by the 
budget, resulting in the unlevered profit percentage from the total budget. As a rule in real estate development, developers are said to always make approximately fifteen percent of profit over total costs. Profit over budget is a prototypical input in a development pro forma because the industry standard is to have a fifteen percent (15\%) surplus of profit over the capital value of the asset (Ratcliffe et. al, 2004). Distinct from internal rate of return (IRR), profit over budget is applied because "back of the envelope" pro formas do not typically include a yearly cash flow, leading to the inability to provide a year-over-year IRR. Lastly, the returns section has a profit over equity percentage, resulting in a value indicating the total profits divided by equity. This results in the equity multiple (profit divided by equity plus one), seeing how much your equity grows over the life of the project. The equity multiple is crucial for understanding the origins and intentions of project investors, as this gives them a rate to evaluate the prospects of the investment.

\subsection{Impact of Inclusionary Zoning}

After thoroughly understanding the fundamentals of the interplay between land development and financial modeling and performance, the method of measuring the impact of inclusionary zoning is straight forward exercise. The measure of impact is based on the constant of the equity multiple, ensuring an invariable rate of return over the life of the project. Other variables, such as gross floor area and density will shift with each of the three (3) models.

The impact of inclusionary zoning will be measured by changing crucial variables in both the development budget section and revenue section. Specifically, this document will measure the impact on land prices and market resale prices per sqf because of their rapid growth and variability over the last decade, as illustrated in Figure 11. 


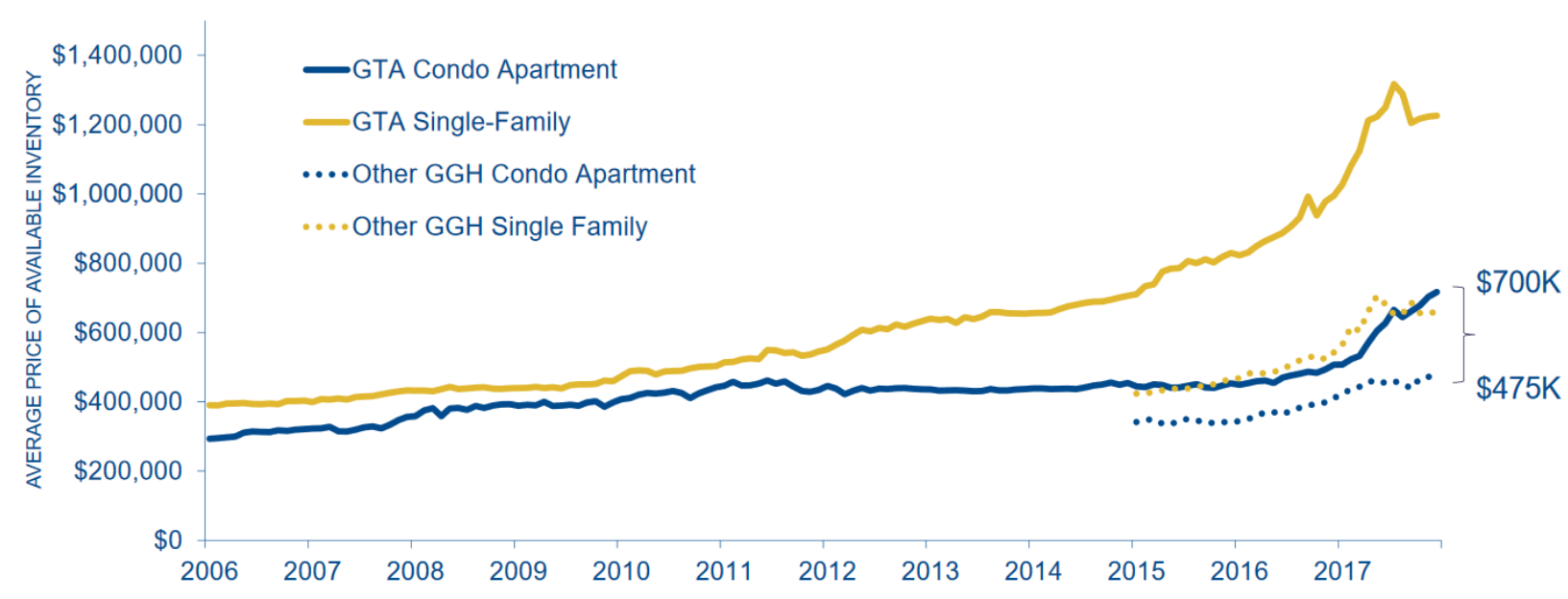

Figure 11 - Greater Toronto Area Housing Prices Since 2006, by Housing Type Source: Altus Group, 2018 


\subsection{RESULTS AND PROBLEM INVESTIGATION}

\subsection{Pro Forma Sensitivity Analysis Findings}

The findings are segregated amongst the three (3) different models, representing different area circumstances and inputs into the pro forma. Each default model incorporates inclusionary units, using the proposed guidelines of a $10 \%$ set-aside amount of residential NSA (Net Saleable Area), at an average of $\$ 516$ / sqf, as per this document's predicted measure of affordability. All models result in less optimal financial returns for developers and private equity firms because of the reduced profits due to inclusionary zoning. Nevertheless, when considering the perspective of the Ministry of Municipal Affairs and the Affordable Housing Office, the proposed regulations have the potential to create affordable home ownership in Toronto, with an average of seventy (70) units created for a single development in each model.

\subsubsection{King Street West \& Spadina Avenue}

Assuming a high quality of construction throughout all three models, the King Spadina pro forma assumes the highest cost of land and condominium / sqf compared to the other models. Using Altus data from 2018, an average land price (/ buildable sqf) price of $\$ 280$ was used, resulting in a total cost of approximately $\$ 133$ million for the 21,000 sqf parcel (Appendix D).

The price / sqf determination is a more nuanced and variable input, using Mid-2017 to January2018 project launch price points, namely Theatre District Residences by Plaza at $\$ 969$ /sqf and Artist's Alley 2 by Lanterra Developments at $\$ 1,050$ /sqf. This model assumed a price point of $\$ 900$ /sqf to remain conservative in a rapidly shifting market (Altus, 2018). 
The default model currently provides a $1.26 x$ equity multiple, and a four percent (4\%) profit over budget, resulting in an sub-optimal project in terms of financial returns from the perspective of real estate developers and financial institutions. When assuming a $2.0 x$ equity multiple, the land costs must fall to $\$ 212$ / buildable sqf, resulting in a $\$ 68$ / buildable sqf difference. When looking at the aggregate, the land owner(s) for this parcel would be looking at an approximate $\$ 33$ million loss when adequately conforming the developer's standards of return of a $2.0 x$ equity multiple and a fifteen percent (15\%) profit over budget.

If the price of the condominium market price / sqf were to be adjusted to match developer profit targets of a $2.0 x$ equity multiple and fifteen percent (15\%) profit over budget, the condominium market price / sqf would rise from $\$ 900$ / sqf to $\$ 1,014$ / sqf, resulting in a $\$ 114$ /sqf increase of prices of market value condos. For reference, this would increase the average price of a unit in the building from $\$ 437,484$ to $\$ 492,878$.

Preliminarily, it can be observed that inclusionary zoning has the potential to adversely impact development in an exceedingly expensive area such as King-Spadina, bearing in mind the cost of land and construction. Alternative approaches to the policy would need to be considered in order to effectively implement the mandatory inclusion of below market-value housing units.

\subsubsection{Yonge Street and Eglinton Avenue (East \& West)}

For the Yonge Street and Eglinton Avenue model, the land price assumption is slightly lower than King-Spadina, totalling $\$ 275$ / buildable GFA. The rationale for this comes directly from aggregated price data from Altus Group, per the adjacent land transactions within a 500m range, as seen in Appendix E. 
Essentially occurring in conjunction with each other, the condominium price / sqf for YongeEglinton also totals slightly lower than King-Spadina at $\$ 880$ / sqf, due to the market forces as outlined by Altus (Altus Group, 2018).

As seen in Appendix B, the default model currently provides a 1.18x equity multiple, and a three percent $(3 \%)$ profit over budget, again resulting in a suboptimal project from the perspective of real estate developers and financial institutions. When assuming a 2.0x equity multiple, the land costs must fall to $\$ 200$ / buildable sqf, resulting in a $\$ 75$ / buildable sqf loss for land owners. When looking at the aggregate, the land owner(s) for this parcel at Yonge-Eglinton would be facing an approximate $\$ 35$ million loss when adequately conforming the developer's standards of return of a 2.0x equity multiple and a fifteen percent (15\%) profit over budget.

When utilizing an input of a $2.0 x$ equity multiple and a fifteen percent (15\%) profit over budgets, the impact of inclusionary zoning would result in a price increase in the condominium market price to $\$ 126$ / sqf. For reference, this would also increase the average price of $90 \%$ of the residential GFA in the building from $\$ 427,762$ to $\$ 488,804$ / unit, more than a $\$ 50,000$ increase.

Similar to the above King-Spadina findings, this document can preliminarily conclude that the impact of inclusionary zoning has the potential to adversely impact real estate development, as one of land prices or market-value condominium price / sqf would be required to increase to achieve the desired project return for this area.

\subsubsection{Bloor Street West and Dundas Street West}


Lastly, the key assumptions for the Bloor Street West and Dundas Street model assumes a land price of $\$ 250$ / buildable sqf and a condo market price of $\$ 870$ / sqf. Also taken from Altus (2018), the inputs are more conservative assumptions based off of the market data in the Bloor-Dundas area, as seen in Appendix $\mathbf{F}$.

As observed in Appendix C, the default model currently provides a 1.44x equity multiple, and a seven percent (7\%) profit over budget, performing marginally better than the previous two sites, but still resulting in a financially suboptimal project for real estate developers. When assuming a 2.0x equity multiple, the land costs must fall to $\$ 202$ / buildable sqf, resulting in a $\$ 48$ / buildable sqf loss for land owners. When looking at the aggregate, the land owner(s) for this parcel at BloorDundas would be facing an approximate $\$ 23$ million loss when adequately conforming the developer's standards of return of a $2.0 x$ equity multiple and a fifteen percent (15\%) profit over budget.

When observing the impacts of inclusionary zoning policies on the market price /sqf for condominium units, there is a price increase of $\$ 81$ /sqf. When looking at the average price increase per condominium unit, this will result in approximate price increase from $\$ 422,901$ to $\$ 462,428$, almost a $\$ 40,000$ upsurge.

When reviewing the results, inclusionary zoning policies appear to have the most limited impact on this area, when comparing to the King-Spadina and Yonge-Eglinton models. While market prices for the condos still increase in all three models, the Bloor-Dundas model has the lowest increase of $\$ 40,000$ / unit.

\section{$\underline{4.2 \text { - Statistics, Narratives \& Design Tools }}$}


Real estate development is a multi-faceted involving hundreds of different people and professions that ultimately depend on the impact market forces. Development requires a tremendous amount of risk because of the many stakeholders that can and will impact the project during initial design and construction. Analyzing the impact of inclusionary zoning on specifically land prices and condo revenue is the current best measure to see immediate market impacts of the proposed provincial policies, but there are many other variables that can impact prices and return. If inclusionary zoning can't be capitalized in reduced pre-development land values, the market will subsequently assume the burden of the costs.

Another problem area surrounds the identification and definition of specific locations, incomes, and rents by the City of Toronto. The proposed inclusionary zoning regulations put out by the province in December of 2017 outline that the city's official plan and zoning by-law shall determine where the maximum of five to ten percent $(5 \%-10 \%)$ of residential NSA become affordable for ownership. Each pro forma model responds better in terms of acceptable return when only enforcing $5 \%$ (five percent) of units be set-aside for affordability, potentially increasing the aggregate of affordable units throughout the city in its entirety.

The definition of affordability could drastically alter the outcomes of the pro forma. As seen in Table 5, this document roughly uses the City of Toronto definition for affordable home ownership, including a down payment of $10 \%$ and monthly payments not exceeding the affordable rental rates, as determined by $\mathrm{CMHC}$. The pro forma model's returns would be improved when implementing the housing affordability criteria as set out in section 6.0 (a) (2) of the PPS, 2015: "housing for which the purchase price is at least 10 percent below the average purchase price of a resale unit in the regional market area;" (PPS, 2015). Using just the King-Spadina pro forma model, the developer's equity multiple increases from $1.26 \mathrm{x}$ to $1.38 \mathrm{x}$ when using the revised definition, resulting in an average affordable price / sqf increase from $\$ 516$ to $\$ 810$. 
The last key assumption that impact the pro forma results was the incentives provided to the developer from the municipality in the form of a forty percent (40\%) rebate. Calculated based on lost revenue from sales, the rebate is required to be provided by the city in exchange for the provision of affordable housing. While this gesture has the potential to be helpful when considering measures of return, the current pro forma models show very little impact from slight alterations of this rebate percentage. The project appears to have fundamental financial return flaws from the outset, creating a problematic situation between the government, private residential real estate developers, and affordable housing providers and operators. 


\subsection{RECOMMENDATIONS AND ALTERNATIVE APPROACHES}

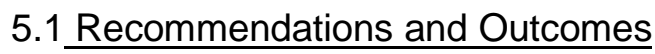

As it stands in today's market, inclusionary zoning places the burden on land owners and condominium purchasers because of the substandard rate of return the policy imposes on real estate developers. When including a set-aside of ten percent $(10 \%)$ of affordable units, the projects are not financially feasible without the increased subsidy of land owners, condo purchasers, or the government. Conversely, the negligible rate of return for real estate developers will directly result in the creation of affordable ownership units in Toronto, with each model providing approximately seventy (70) units below market rate. Directly based on the pro forma results seen in appendices 1-3, new developments incorporating and adhering to mandatory inclusionary zoning programs are providing significantly less financial incentives for real estate developers at the outset of the project, requiring major adjustments in the crucial assumptions discussed above. Conceptually, inclusionary zoning can be understood as market-rate units subsidizing affordable housing for those with lower incomes.

With the draft framework in place by the Province of Ontario, inclusionary zoning will likely exist in the form of future amendments to Toronto's Official Plan and Zoning By-law. The direction of residential real estate development industry should aim in the direction of exploring methods of mitigating price impacts of future inclusionary zoning policies. 
Essentially taxing new housing, this practice is not limited to the scope of this project. In Los Angeles County, city council voted to create a "linkage fee" in December of 2017, placing a nominal dollar / sqf surcharge on more affluent neighbourhoods in the north side of the city to be contributed towards the preservation of affordable housing in the south side of the city (Smith, 2017). Linkage fees are possibly more transparent of a policy than inclusionary zoning, as it is still currently unclear which stakeholders will be subsidizing the development of affordable housing in Toronto. This document proves what impacts will be on the stakeholder who assumes the burden of the decreased revenues, between land owners and market rate condominium purchasers.

\subsection{Alternative Approaches}

The pro forma approach heavily relied upon in this document is best viewed as a guide to how development financing functions as opposed to a stringent regimen. Known as a "back of the envelope" analysis, the pro forma model comprised of a single sheet with all important and significant cost assumptions, but did not include a cash flow statements, indicating the sources and uses of debt and equity. Future analysis in the Toronto-specific market could contribute further details surrounding specific measures and assumptions of the pro forma, using an advanced model with cash flow statements determining the internal rate of return over the life of the project.

\footnotetext{
${ }^{1}$ Coined in the United States in the 1970's, linkage fees are used to associate the development of market housing to the development of affordable units. Typically administered by a square foot basis, linkage fees were initially created for the purposes of commercial developments, where on-site housing is typically deemed inadmissible or problematic. Linkage fees are intended to mitigate the housing price increases that accompany market rate development (Keating, 1986)
} 
The pro forma analysis conducted for the purposes of this MRP singled out the dependent variable of land costs or condominium price / sqf when comparing the standardized measures of return of a $2.0 x$ equity multiple or $15 \%$ profit over costs. In reality, there are a multitude of effects that can and will happen, impacting many variables simultaneously. Mandatory inclusionary zoning policies would impact both land prices and market prices conjointly, among other factors during the analysis of the pro formas. Government policies have the potential to impact different facets of how cities function and grow, as opposed to inflexible figures the pro formas identified. The true impact on prices could be somewhere in the middle of what section 3.0 identified, as these proposed policies could impact land prices, market condominium prices / sqf, parking revenue, commercial revenue, etc.

Another approach could consider the terms and definition of affordability in the Official Plan. Affordability differs by geographic area, as Figure 12 includes a map of average income by census tract area in the City of Toronto. Uniform affordability standards for the entire city could be an ineffective approach of determining an accurate measure of affordability, as each census tract varies throughout the city. 


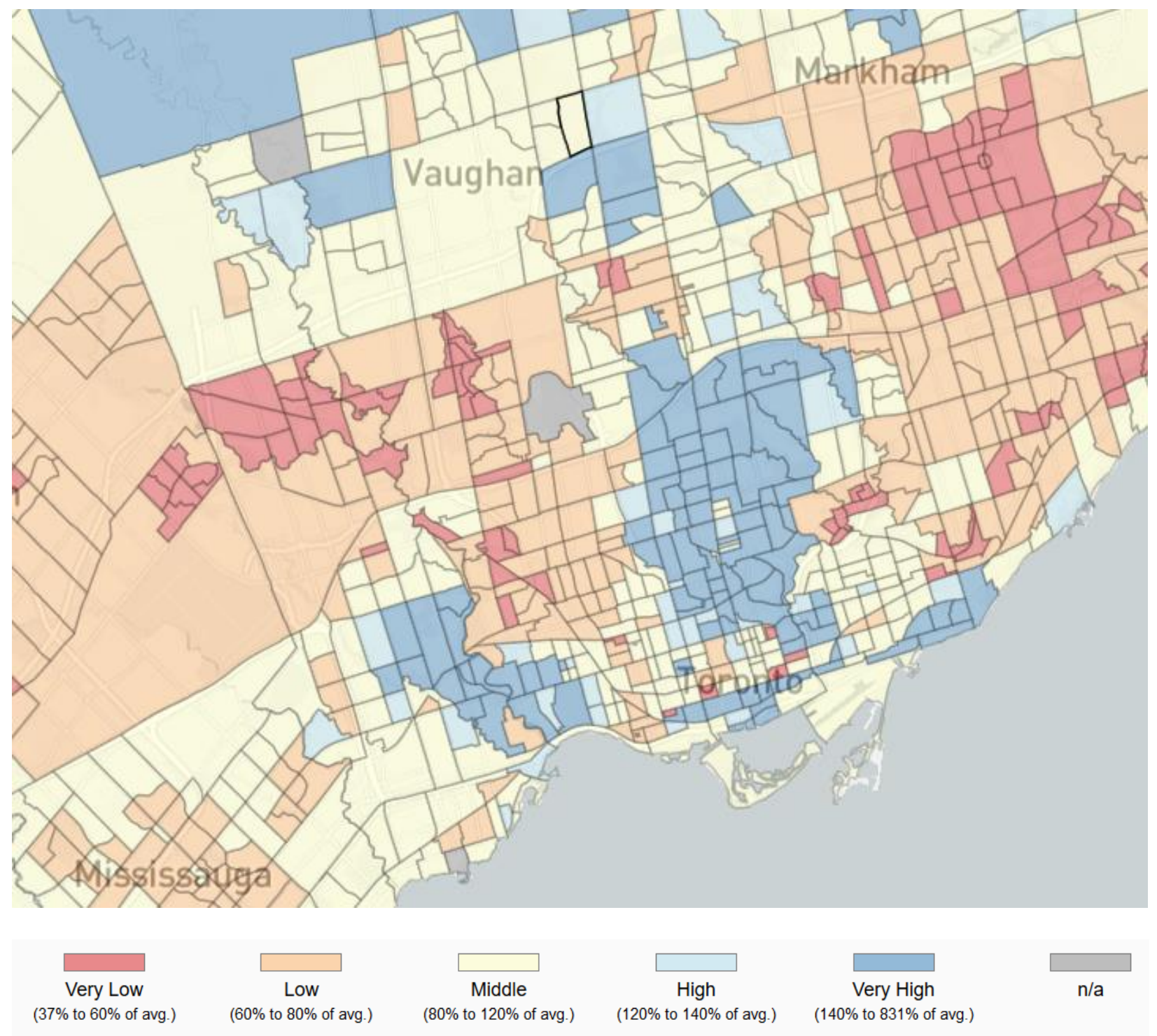

Figure 12 - 2015 Census Tract Average Individual Income vs. Toronto CMA Average of $\$ 50,479$ Source: Tulk and Grzincic, 2017

Implementing varying measures of affordability throughout each census tract combined with fluctuating levels of government rebate would provide developers an option to look at more creative ways to incorporate affordable housing, as opposed to strictly enforcing rigid rules. The current measure of forty percent (40\%) is loosely defined in the proposed guidelines and has the potential to increase the production of affordable housing if it was increased in certain census tracts and vice versa. 
The proposed regulations note that the increase of height and/or density due to the inclusion of affordable units will not be valid for arbitrating section 37 agreements by the developer nor city councillors. If developers were able to include the minimum or excess of the ten percent (10\%) in proximity to higher order transit areas, they could be better equipped to finance the project when paying less section 37 benefits in exchange for additional affordable housing.

\subsection{Next Steps}

The above outlined the potential for negative and detrimental impacts of inclusionary zoning if implemented in the Official Plan and Zoning By-law in Toronto. The proposed policies by the province must shift if affordable housing is to be created at the desired rate. Notably, the proposed guidelines exclude rental units, a major criticism from Toronto's Affordable Housing Office, from a January 2018 staff report. Recommendation 2 from the report notes that: "The proposed regulation should be amended to explicitly provide for the opportunity to create new affordable purpose-built rental housing" (Affordable Housing Office, 2018). Rental housing is more accessible to low income individuals, requiring no down payment and reduced maintenance / repair expenses versus home ownership. As the Affordable Housing office notes, the proposed regulations should not be restricted to exclusively home ownership opportunities, allowing for additional policy options for the developer and the city. In a perfect world, effective inclusionary zoning policies would allow developers to receive their targeted rate of return while including the provision of affordable housing, producing housing opportunities to society's low-income individuals. To ensure the effective implementation of inclusionary zoning policies, Toronto's Official Plan and Zoning By-laws should outline variable measures of affordability throughout the city, as opposed to prescribing one specific target purchase price / sqf across the entire city. 


\section{APPENDIX A - King-Spadina Pro Forma}

\section{Site Statistics}

\section{Project Name}

Site Area

Allowable Density

Total Gross Floor Area (Above-Grade)

Residential Gross Floor Area

Commercial Gross Floor Area

Net Sellable Area

Net Sellable Area - Residential

Net Sellable Area - Commercial

Net Sellable Area - Residential (IZ)

NEW Net Sellable Area - Residentia

Gross Construction Area

Average Unit Size

Bachelor \& 1-Bedroom

2-Bedroom

3-Bedroom

Residential Units

Bachelor \& 1-Bedroom

2-Bedroom

3-Bedroom

Lockers

Total Unit Sqf

Bachelor \& 1-Bedroom

2-Bedroom

3-Bedroom

Residential Parking

\section{Project Returns}

\begin{tabular}{lr}
\hline Total Revenue & $\$ 346,978,441$ \\
Total Budget & $\$ 334,011,026$ \\
Total Profit & $\$ 12,967,415$ \\
Equity Required & $\$ 50,101,654 \quad 15 \%$ Loan to Cost \\
Profit: Budget & $4 \%$ \\
Profit: Equity & $26 \%$ \\
Equity Multiple & $1.26 \mathrm{x}$
\end{tabular}

\section{Development Budget}

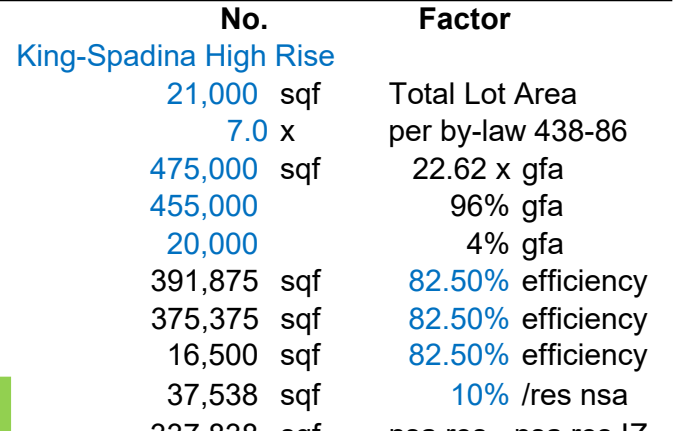

337,838 sqf nsa res - nsa res IZ

500,000 sqf

540 sqf

450 sqf

650 sqf

800 sqf

695 units

$50 \%$ units

$40 \%$ units

$10 \%$ units

695 lockers

695 units

417 units

231 units

47 units

375,375 sqf

187,688 sqf

150,150 sqf

37,538 sqf

292 spaces

0.42 / unit

Land

Construction Costs - Hard

Construction Costs - Soft

$\$ 133,000,000$

$\$ 135,000,000$

Design

$\$ 40,500,000$

$\$ 2,432,518$

$\$ 2,780,021$

$\$ 3,475,026$

Marketing, Sales, \& Leasing

$\$ 195,938$

Finance Realted Costs $\$ 3,127,523$

Contingency

Total Project Costs

$\$ 334,011,026$

\section{Revenue}

Condo

Condo

Bachelor \& 1-Bedroom

$\$ 304,053,750$

$\$ 19,383,346$

3-Bedroom

$\$ 1,618,805$

Residential Parking

$\$ 1,618,805$

Locker

$\$ 6,950,052$

Gross Sales Revenue

HST

$\$ 344,982,258$

$-\$ 27,564,082$

Lost Revenue from IZ

$\$ 14,400,404$

$40 \%$ Government Rebate for IZ \$5,760,161

Net Sales Revenue

Closing Adjustments

$\$ 323,178,337$

Total Residential Revenue

Commercial Revenue

$\$ 13,900,104$

$\$ 337,078,441$

Total Project Revenue

$\$ 9,900,000$

$\$ 346,978,441$

.

Factor

$\$ 280 / g$

$\$ 270$ /gca

$\$ 194,243.15$ /unit

$30 \%$ /hard costs $\$ 58,272.94$ /unit

$\$ 3,500$ /unit $\quad \$ 3,500.00$ /unit

$\$ 4,000$ /unit $\quad \$ 4,000.00$ /unit

$\$ 5,000$ /unit $\$ 5,000.00$ /unit

$\$ 0.50$ /sqf

$\$ 4,500$ /unit

$\$ 281.92$ /unit

$\$ 4,500.00$ /unit

$10 \%$ /hard costs $\$ 19,424.31$ /unit $\$ 480,587.80$ /unit

$\begin{array}{cr}\text { Factor } & \mathbf{6 9 5} \text { Units } \\ \$ 900 \text { /sqf } & \$ 437,484.13 \text { /unit } \\ \$ 516 \text { /sqf } & \$ 27,889.50 \text { /unit } \\ \$ 571 \text { /sqf } & \$ 15,422.97 \text { /unit } \\ \$ 469 \text { /sqf } & \$ 10,137.33 \text { /unit } \\ \$ 431 \text { /sqf } & \$ 2,329.20 \text { /unit } \\ \$ 50,000 \text { /space } & \$ 21,000.00 \text { /unit } \\ \$ 10,000 \text { /locker } & \$ 10,000.00 \text { /unit } \\ & \$ 496,373.63 \text { /unit } \\ 7.99 \% & -\$ 39,660.25 \text { /unit } \\ \$ 384 \text { /sqf } & \$ 20,719.85 \text { /unit } \\ 40 \% \text { rebate } & \$ 8,287.94 \text { /unit } \\ & \$ 465,001.32 \text { /unit } \\ \$ 20,000 \text { /unit } & \$ 20,000.00 \text { /unit } \\ & \$ 485,001.32 \text { /unit } \\ \$ 600 \text { /sqf } & \$ 14,244.50 \text { /unit } \\ & \$ 499,245.81 \text { /unit }\end{array}$




\section{APPENDIX B - Yonge-Eglinton Pro Forma}

\section{Site Statistics}

Project Name

Site Area

Allowable Density

Total Gross Floor Area (Above-Grade)

Residential Gross Floor Area

Commercial Gross Floor Area

Net Sellable Area

Net Sellable Area - Residential

Net Sellable Area - Commercial

Net Sellable Area - Residential (IZ)

NEW Net Sellable Area - Residential

Gross Construction Area

Average Unit Size

Bachelor \& 1-Bedroom

2-Bedroom

3-Bedroom

Residential Units

Bachelor \& 1-Bedroom

2-Bedroom

3-Bedroom

Lockers

Total Unit Sqf

Bachelor \& 1-Bedroom

2-Bedroom

3-Bedroom

Residential Parking

4. Project Returns

Total Revenue

Total Budget

Total Profit

Equity Required

Profit: Budget

Profit: Equity

Equity Multiple

\section{No.}

Yonge-Eglinton High Rise

$5.0 \mathrm{x}$

475,000 sqf

455,000

20,000

391,875 sqf

375,375 sqf

16,500 sqf

37,538 sqf

337,838 sqf

500,000 sqf

540 sqf

450 sqf

650 sqf

800 sqf

695 units

$50 \%$ units

$40 \%$ units

$10 \%$ units

695 lockers

695 units

417 units

231 units

375,375 sqf

187,688 sqf

150,150 sqf

37,538 sqf

$$
292 \text { spaces }
$$

0.42 / unit

Total Lot Area

$2.62 \times \mathrm{gfa}$

$96 \%$ gfa
$4 \%$ gfa

1 /unit per by-law 569-2013

$82.50 \%$ efficiency

$82.50 \%$ efficiency

$82.50 \%$ efficiency

$10 \% /$ res nsa

nsa res - nsa res IZ

$\$ 340,461,255$

$\$ 331,636,026$

$\$ 8,825,229$

$\$ 49,745,404$

$3 \%$

$18 \%$

$1.18 \times$

\section{Development Budget}

No.

Construction Costs - Hard $\$ \$ 135,000,000$

Construction Costs - Soft $\$ \$ 4,500,000$

Design

$\$ 2,432,518$

Legal \& Administration

$\$ 2,780,021$

Marketing, Sales, \& Leasing $\quad \$ 3,475,026$

Occupancy Operating Expenses $\$ 195,938$

Finance Realted Costs \$3,127,523

Contingency

Total Project Costs

$\$ 13,500,000$

$\$ 331,636,026$

Factor

$\$ 275$ /gfa

$30 \%$ /hard costs $\$ 58,272.94$ /unit

$\$ 3,500$ /unit $\$ 3,500.00$ /unit

$\$ 4,000$ /unit $\quad \$ 4,000.00$ /unit

$\$ 5,000$ /unit $\quad \$ 5,000.00$ /unit

$\$ 0.50$ /sqf $\quad \$ 281.92$ /unit

$\$ 4,500$ /unit $\$ 4,500.00$ /unit

$10 \%$ /hard costs $\$ 19,424.31 /$ unit

\section{Revenue}

Condo

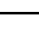

Bachelor $\&$

Bachelor \&

3-Bedroom

Residential Parking

Locker

Gross Sales Revenue

HST

Lost Revenue from IZ

$40 \%$ Government Rebate for IZ

Net Sales Revenue

Closing Adjustments

Total Residential Revenue

Commercial Revenue

Total Project Revenue

15\% Loan to Cost
No.

$\$ 297,297,000$

$\$ 19,383,346$

$\$ 10,719,042$

$\$ 7,045,500$

$\$ 1,618,805$

$\$ 14,595,109$

$\$ 6,950,052$

$\$ 338,225,508$

$-\$ 27,024,218$

$\$ 13,649,654$

$\$ 5,459,861$

$\$ 316,661,151$

$\$ 13,900,104$

$\$ 330,561,255$

$\$ 9,900,000$

$\$ 340,461,255$
Factor

$\$ 880$ /sqf

$\$ 516$ /sqf

$\$ 571$ /sqf

$\$ 469$ /sqf

$\$ 431$ /sqf

$\$ 50,000$ /space

$\$ 10,000$ /locker

$7.99 \%$

$\$ 364$ /sqf

$40 \%$ rebate

$\$ 20,000$ /unit

$\$ 600$ /sqf
$\$ 477,170.56$ /unit

695 Units

$\$ 427,76226$ /unit

$\$ 27,889.50$ /unit

$\$ 15,422.97$ /unit

$\$ 2,329.20$ /unit

$\$ 21,000.00$ /unit

$\$ 10,000.00$ /unit

$\$ 486,651.76$ /unit

-\$38,883.48/unit

$\$ 19,639.64$ /unit

$\$ 7,855.86$ /unit

$\$ 455,624.14$ /unit

$\$ 20,000.00$ /unit

$\$ 475,624.14$ /unit

$\$ 14,244.50$ /unit

$\$ 489,868.64$ /unit
$\$ 10,137.33$ /unit 


\section{APPENDIX C - Bloor-Dundas Pro Forma}

\section{Site Statistics}

Project Name

Site Area

Allowable Density

Total Gross Floor Area (Above-Grade)

Residential Gross Floor Area

Commercial Gross Floor Area

Net Sellable Area

Net Sellable Area - Residential

Net Sellable Area - Commercial

Net Sellable Area - Residential (IZ)

NEW Net Sellable Area - Residential

Gross Construction Area

Average Unit Size

Bachelor \& 1-Bedroom

2-Bedroom

3-Bedroom

Residential Units

Bachelor \& 1-Bedroom

2-Bedroom

3-Bedroom

Lockers

Total Unit Sqf

Bachelor \& 1-Bedroom

2-Bedroom

3-Bedroom

Residential Parking

4. Project Returns

Total Revenue

Total Budget

Total Profit

Equity Required

Profit: Budget

Profit: Equity

Equity Multiple

$$
\text { No. }
$$

No.
Bloor-Dufferin High Rise

$21,000 \mathrm{sq}$

$$
6.0 \mathrm{x}
$$

475,000 sqf

455,000

20,000

391,875 sqf

375,375 sqf

16,500 sqf

37,538 sqf

337,838 sqf

500,000 sqf

540 sqf

450 sqf

650 sqf

800 sqf

695 units

$50 \%$ units

$40 \%$ units

$10 \%$ units

695 lockers

695 units

417 units

231 units

47 units

375,375 sqf

187,688 sqf

150,150 sqf

37,538 sqf

$$
292 \text { spaces }
$$

0.42 / unit

$\$ 337,202,663$

$\$ 316,261,026$

$\$ 20,941,636$

$\$ 47,439,154$

$7 \%$

$44 \%$

$1.44 \mathrm{x}$

1 /unit

$15 \%$ Loan to Cost

\section{Development Budget}

Land

Construction Costs - Hard

Design

Legal \& Administration

$2.50 \%$ efficiency

$82.50 \%$ efficiency

$82.50 \%$ efficiency

$10 \%$ /res nsa

nsa res - nsa res IZ

Occupancy Operating Expenses

Finance Realted Costs

Contingency

Total Project Costs

\section{Revenue}

Condo

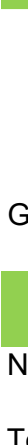

Bachelor \& 1-Bedroom
2-Bedroom
3-Bedroom
Residential Parking
Locker
Gross Sales Revenue

HST

Lost Revenue from IZ

$40 \%$ Government Rebate for IZ

Net Sales Revenue

Closing Adjustments

Total Residential Revenue

Commercial Revenue

Total Project Revenue

$\$ 337,202,663$

No.

No.

$\$ 132,500,000$

$\$ 39,750,000$

$\$ 2,432,518$

$\$ 2,780,021$

$\$ 3,475,026$

$\$ 195,938$

$\$ 3,127,523$

$\$ 13,250,000$

$\$ 316,261,026$

$\begin{array}{cr}\text { Factor } & 695 \text { Units } \\ \$ 250 \text { /gfa } & \$ 170,862.03 \text { /unit } \\ \$ 265 \text { /gca } & \$ 190,646.05 \text { /unit } \\ 30 \% \text { /hard costs } & \$ 57,193.82 \text { /unit } \\ \$ 3,500 \text { /unit } & \$ 3,500.00 \text { /unit } \\ \$ 4,000 \text { /unit } & \$ 4,000.00 \text { /unit } \\ \$ 5,000 \text { /unit } & \$ 5,000.00 \text { /unit } \\ \$ 0.50 \text { /sqf } & \$ 281.92 \text { /unit } \\ \$ 4,500 \text { /unit } & \$ 4,500.00 \text { /unit } \\ 10 \% \text { /hard costs } & \$ 19,064.61 \text { /unit } \\ & \$ 455,048.43 \text { /unit }\end{array}$

Factor

$\$ 870$ /sqf

$\$ 516$ /sqf

$\$ 571$ /sqf

$\$ 469$ /sqf

$\$ 431$ /sqf

$\$ 7,045,500$

$\$ 1,618,805$

$\$ 14,595,109$

$\$ 6,950,052$

$\$ 334,847,133$

$-\$ 26,754,286$

$\$ 13,274,279$

$\$ 5,309,711$

$\$ 313,402,558$

$\$ 13,900,104$

$\$ 327,302,663$

$\$ 9,900,000$
$\$ 50,000$ /space

$\$ 10,000$ /locker

$7.99 \%$

$\$ 354$ /sqf

$40 \%$ rebate

$\$ 20,000$ /unit

$\$ 600$ /sqf
695 Units

$\$ 422,901.33$ /unit $\$ 27,889.50$ /unit $\$ 15,422.97$ /unit $\$ 10,137.33$ /unit $\$ 2,329.20$ /unit $\$ 21,000.00$ /unit $\$ 10,000.00$ /unit $\$ 481,790.83$ /unit -\$38,495.09/unit $\$ 19,099.54$ /unit $\$ 7,639.82$ /unit $\$ 450,935.55$ /unit $\$ 20,000.00$ /unit $\$ 470,935.55$ /unit $\$ 14,244.50$ /unit $\$ 485,180.05$ /unit 
APPENDIX D - Residential Land Transactions within 500m of King-Spadina Node Since 1995 (Source: Altus Group, 2018)

\begin{tabular}{|c|c|c|c|c|c|c|}
\hline Date & Municipal Address & Purchase Price & Size (Acres) & Price / Acre & Price / Buildable Sf & Price / Unit \\
\hline $2018-01-17$ & 24 Mercer Street & $\$ 6,750,000.00$ & 0.05 & $\$ 135,000,000.00$ & $\$ 191.00$ & $\$ 562,500.00$ \\
\hline $2017-12-22$ & 143 Portland Street & $\$ 1,330,000.00$ & 0.037 & $\$ 35,945,945.95$ & & \\
\hline $2017-12-19$ & 40 - 58 Widmer Street & $\$ 75,200,000.00$ & 0.378 & $\$ 198,941,798.94$ & $\$ 261.00$ & $\$ 176,526.00$ \\
\hline 2017-12-01 & 595-603 King Street West & $\$ 20,000,000.00$ & 0.168 & $\$ 119,047,619.05$ & & \\
\hline 2017-11-02 & $445,447 \& 451$ Adelaide Street West & $\$ 4,950,000.00$ & 0.106 & $\$ 46,698,113.21$ & & \\
\hline $2017-10-06$ & 449 Adelaide Street West & $\$ 1,500,000.00$ & 0.03 & $\$ 50,000,000.00$ & & \\
\hline $2017-09-27$ & 565 King Street West & $\$ 2,700,000.00$ & 0.031 & $\$ 87,096,774.19$ & & \\
\hline 2017-07-18 & $321,325 \& 327$ King Street West & $\$ 45,000,000.00$ & 0.292 & $\$ 154,109,589.04$ & $\$ 198.00$ & $\$ 148,026.00$ \\
\hline 2017-06-14 & 359 Richmond Street West & $\$ 3,458,745.00$ & 0.028 & $\$ 123,526,607.14$ & $\$ 90.00$ & $\$ 60,979.00$ \\
\hline 2017-01-17 & 387 - 391 Adelaide Street West & $\$ 8,250,000.00$ & 0.186 & $\$ 44,354,838.71$ & & \\
\hline 2017-01-05 & 456 Wellington Street West & $\$ 13,000,000.00$ & 0.241 & $\$ 53,941,908.71$ & & \\
\hline Yearly Average & & & & $\$ 95,333,017.72$ & $\$ 185.00$ & $\$ 237,007.75$ \\
\hline $2016-12-15$ & 400 - 420 King Street West & $\$ 50,511,000.00$ & 0.654 & $\$ 77,233,944.95$ & & \\
\hline 2016-09-27 & 135 Portland Street & $\$ 2,200,000.00$ & 0.045 & $\$ 48,888,888.89$ & & \\
\hline 2016-09-19 & 137 Portland Street & $\$ 2,700,000.00$ & 0.038 & $\$ 71,052,631.58$ & & \\
\hline 2016-09-08 & 497, 505 \& 511 Richmond Street West & $\$ 26,000,968.00$ & 1.279 & $\$ 20,329,138.39$ & $\$ 77.00$ & $\$ 86,960.00$ \\
\hline 2016-07-04 & 451 Richmond Street West & $\$ 6,500,000.00$ & 0.105 & $\$ 61,904,761.90$ & $\$ 105.00$ & $\$ 79,856.00$ \\
\hline 2016-07-04 & 444 - 450 Richmond Street West & $\$ 6,500,000.00$ & 0.151 & $\$ 43,046,357.62$ & & \\
\hline 2016-06-24 & 123 Portland Street & $\$ 1,350,000.00$ & 0.044 & $\$ 30,681,818.18$ & & \\
\hline $2016-05-12$ & 40 - 58 Widmer Street & $\$ 30,250,000.00$ & 0.378 & $\$ 80,026,455.03$ & $\$ 104.00$ & $\$ 71,009.00$ \\
\hline 2016-05-11 & 141 Portland Street & $\$ 2,380,000.00$ & 0.037 & $\$ 64,324,324.32$ & & \\
\hline 2016-04-28 & 101 Spadina Avenue & $\$ 20,000,000.00$ & 0.226 & $\$ 88,495,575.22$ & & \\
\hline 2016-04-26 & 350 Adelaide Street West & $\$ 1,485,000.00$ & 0.002 & $\$ 742,500,000.00$ & & \\
\hline 2016-04-11 & 422 - 424 Wellington Street West & $\$ 8,300,000.00$ & 0.341 & $\$ 24,340,175.95$ & $\$ 64.00$ & $\$ 64,341.00$ \\
\hline 2016-02-18 & 57 Spadina Avenue & $\$ 32,900,000.00$ & 0.42 & $\$ 78,333,333.33$ & $\$ 106.00$ & $\$ 105,112.00$ \\
\hline Yearly Average & & & & $\$ 110,089,031.18$ & $\$ 91.20$ & $\$ 81,455.60$ \\
\hline $2015-12-10$ & 47 Camden Street & $\$ 4,500,000.00$ & 0.059 & $\$ 76,271,186.44$ & & \\
\hline $2015-12-08$ & 457 Richmond Street West & $\$ 4,600,000.00$ & 0.104 & $\$ 44,230,769.23$ & $\$ 105.00$ & $\$ 79,856.00$ \\
\hline $2015-08-27$ & 3- 7 Cameron Street & $\$ 4,000,000.00$ & 0.0976 & $\$ 40,983,606.56$ & $\$ 77.00$ & $\$ 55,055.00$ \\
\hline $2015-08-17$ & 301 King Street West & $\$ 8,000,000.00$ & 0.062 & $\$ 129,032,258.06$ & & \\
\hline $2015-08-06$ & 119 - 121 Portland Street & $\$ 1,300,000.00$ & 0.071 & $\$ 18,309,859.15$ & & \\
\hline 2015-08-06 & 502 Adelaide Street West & $\$ 2,800,000.00$ & 0.115 & $\$ 24,347,826.09$ & & \\
\hline $2015-07-21$ & 485 Wellington Street West & $\$ 6,077,500.00$ & 0.192 & $\$ 31,653,645.83$ & $\$ 81.00$ & $\$ 62,500.00$ \\
\hline $2015-07-21$ & 489 Wellington Street West & $\$ 2,422,500.00$ & 0.094 & $\$ 25,771,276.60$ & $\$ 81.00$ & $\$ 62,500.00$ \\
\hline $2015-07-16$ & 10 Widmer Street & $\$ 7,400,000.00$ & 0.153 & $\$ 48,366,013.07$ & $\$ 37.00$ & $\$ 24,588.00$ \\
\hline $2015-07-16$ & 16 Widmer Street & $\$ 4,300,000.00$ & 0.059 & $\$ 72,881,355.93$ & $\$ 37.00$ & $\$ 24,588.00$ \\
\hline 2015-06-29 & 533 King Street West & $\$ 48,672,286.62$ & 0.682 & $\$ 71,366,989.18$ & & \\
\hline $2015-06-29$ & $511-529$ \& 539 King Street West & $\$ 51,327,713.38$ & 0.827 & $\$ 62,064,949.67$ & & \\
\hline 2015-05-05 & 126 Peter Street & $\$ 3,438,888.88$ & 0.034 & $\$ 101,143,790.59$ & $\$ 90.00$ & $\$ 60,979.00$ \\
\hline 2015-03-27 & 452 - 458 Richmond Street West & $\$ 6,400,000.00$ & 0.135 & $\$ 47,407,407.41$ & $\$ 73.00$ & $\$ 47,407.00$ \\
\hline 2015-03-02 & 357 Richmond Street West & $\$ 2,981,800.00$ & 0.028 & $\$ 106,492,857.14$ & $\$ 90.00$ & $\$ 60,979.00$ \\
\hline $2015-01-15$ & 367 - 369 King Street West & $\$ 7,500,000.00$ & 0.108 & $\$ 69,444,444.44$ & $\$ 117.00$ & $\$ 120,968.00$ \\
\hline 2015-01-07 & 8 Camden Street & $\$ 5,100,000.00$ & 0.113 & $\$ 45,132,743.36$ & & \\
\hline Yearly Average & & & & $\$ 59,700,057.57$ & $\$ 78.80$ & $\$ 59,942.00$ \\
\hline $2014-12-23$ & 170 Spadina Avenue & $\$ 10,920,000.00$ & 0.323 & $\$ 33,808,049.54$ & $\$ 77.00$ & $\$ 55,055.00$ \\
\hline 2014-10-29 & 128 Peter Street & $\$ 6,025,000.00$ & 0.082 & $\$ 73,475,609.76$ & $\$ 90.00$ & $\$ 60,979.00$ \\
\hline 2014-09-15 & 335 - 355 King Street West \& 119 Blue Jays Way & $\$ 113,000,000.00$ & 0.956 & $\$ 118,200,836.82$ & $\$ 156.00$ & $\$ 109,178.74$ \\
\hline 2014-09-15 & 46 Charlotte Street \& 353 Adelaide Street West & $\$ 12,718,740.06$ & 0.137 & $\$ 92,837,518.69$ & $\$ 71.00$ & $\$ 51,285.00$ \\
\hline 2014-08-29 & 122 Peter Street & $\$ 10,621,595.52$ & 0.175 & $\$ 60,694,831.54$ & $\$ 90.00$ & $\$ 60,979.00$ \\
\hline 2014-08-07 & Blue Jays Way & $\$ 1,350,017.00$ & 0.059 & $\$ 22,881,644.07$ & $\$ 109.00$ & $\$ 76,135.00$ \\
\hline 2014-06-27 & 313 - 315 Adelaide Street West & $\$ 12,800,000.00$ & 0.181 & $\$ 70,718,232.04$ & $\$ 58.00$ & $\$ 46,822.00$ \\
\hline 2014-06-19 & 102 Peter Street & $\$ 9,600,000.00$ & 0.19 & $\$ 50,526,315.79$ & & \\
\hline 2014-06-17 & 30 Widmer Street & $\$ 8,785,000.00$ & 0.113 & $\$ 77,743,362.83$ & $\$ 58.00$ & $\$ 46,822.00$ \\
\hline 2014-04-17 & 335 King Street West & $\$ 6,200,000.00$ & 0.0615 & $\$ 100,813,008.13$ & $\$ 109.00$ & $\$ 76,135.00$ \\
\hline 2014-01-28 & 40 - 58 Widmer Street & $\$ 14,500,000.00$ & 0.377 & $\$ 38,461,538.46$ & $\$ 44.33$ & $\$ 38,157.89$ \\
\hline Yearly Average & & & & $\$ 67,287,358.88$ & $\$ 86.23$ & $\$ 62,154.86$ \\
\hline $2013-02-01$ & 52 Widmer Street & $\$ 1,400,000.00$ & 0.038 & $\$ 36,842,105.26$ & $\$ 15.00$ & $\$ 13,169.00$ \\
\hline Yearly Average & & & & $\$ 36,842,105.26$ & $\$ 15.00$ & $\$ 13,169.00$ \\
\hline $2012-10-02$ & 12 Camden Street & $\$ 1,925,000.00$ & 0.057 & $\$ 33,771,929.82$ & & \\
\hline 2012-08-31 & 39 Camden Street & $\$ 2,500,000.00$ & 0.105 & $\$ 23,809,523.81$ & & \\
\hline 2012-08-31 & 438 Adelaide Street West & $\$ 7,100,000.00$ & 0.281 & $\$ 25,266,903.91$ & $\$ 80.00$ & $\$ 54,835.00$ \\
\hline
\end{tabular}


2012-08-01

2012-07-31

2012-07-20

2012-06-29

2012-04-16

2012-04-03

2012-02-13

2012-01-25

2012-01-20

2012-01-12

Yearly Average

2011-12-16

2011-11-02

2011-08-12

2011-07-28

2011-05-31

2011-05-24

2011-04-20

2011-04-15

2011-03-25

2011-03-09

2011-02-24

2011-01-12

Yearly Average

2010-10-01

2010-07-05

2010-06-28

2010-01-15

Yearly Average

2009-02-09

2009-01-29

2008-11-07

2008-07-30

2008-07-11

2008-06-30

2008-06-27

2008-05-30

2008-05-15

2008-05-01

2008-04-15

2008-02-04

2008-01-15

2008-01-10

2008-01-09

2007-09-07

2007-08-17

2007-06-26

2007-05-01

2007-05-01

2007-04-30

2007-02-26

2006-12-22

2006-09-14

2006-07-05

2006-02-06

2006-02-01

2006-01-26

2006-01-10

2005-12-13

2005-10-17

2005-09-15

2005-07-28
520 Richmond Street West

431, 441 - 445 Richmond Street West

620 \& 622A King Street West, 501 \& 505

Adelaide Street West, 1 \& 11 Adelaide Place and $\$ 22,000,000.00$

106 Portland Street

16 \& 18 Camden Street

57 Spadina Avenue

426 - 432 Adelaide Street West

321 King Street West

81 Peter Street

313 - 315 Adelaide Street West

16 Widmer Street

45 Camden Street

355 King Street West \& 119 Blue Jays Way

81 Peter Street

170 Spadina Avenue

434 - 436 Adelaide Street West

306, 310, 318 \& 322 Richmond Street West

326 Richmond Street West

324 \& 332 Richmond Street West

328 Richmond Street West

328 Adelaide Street West

340 Adelaide Street West

122 Peter Street

$\$ 71,250,000.00$

11 Charlotte Street

33 Widmer Street

Adelaide Street West

508,512 \& 516 Wellington Street West

294 Adelaide Street West

299 Adelaide Street West

456 Wellington Street West

369 King Street West

287 Richmond Street West

512 Wellington Street West

60 John Street and 12 Mercer Street

117 Peter Street

560 King Street West

457 Adelaide Street West

56 Blue Jays Way

283 \& 295 Adelaide Street West

500 Wellington Street West

21 Widmer Street

86 John Street

415 King Street West

352 Front Street West

320 - 322 Richmond Street West

Festival Centre

306, 308, 310 \& 318 Richmond Street West

326 King Street West

32 Camden Street

478 King Street West

400 Wellington Street West

3 - 7 Cameron Street

357 King Street West

71 Portland Street

499 King Street West

46 Charlotte Street \& 353 Adelaide Street West

300 Front Street West

79 Portland Street

24 Charlotte Street

371 King Street West
$2,200,000.00$

$\$ 10,500,000.00$

$\$ 4,225,000.00$

$\$ 4,680,000.00$

$\$ 27,512,500.00$

$\$ 8,000,000.00$

$\$ 2,150,000.00$

$\$ 2,300,000.00$

$\$ 7,450,000.00$

$\$ 7,110,000.00$

$\$ 2,000,000.00$

$\$ 20,800,000.00$

$\$ 1,500,000.00$

$\$ 10,400,000.00$

$\$ 1,350,000.00$

$\$ 10,170,000.00$

$\$ 2,000,000.00$

$\$ 3,100,000.00$

0.202

0.316

$\$ 27,227,722.77$

$\$ 24,050,632.91$

$0.783 \quad \$ 28,097,062.58$

$\$ 8,000,000.00$

$\$ 2,100,000.00$

$\$ 2,170,000.00$

$\$ 4,400,000.00$

$\$ 21,000,000.00$

$\$ 8,690,000.00$

$\$ 2,400,000.00$

$\$ 3,200,000.00$

$\$ 4,250,000.00$

$\$ 1,200,000.00$

$\$ 19,924,500.00$

$\$ 8,613,125.00$

$\$ 6,500,000.00$

$\$ 13,500,000.00$

$\$ 18,000,000.00$

$\$ 38,500,000.00$

$\$ 3,600,000.00$

$\$ 18,500,000.00$

$\$ 2,800,000.00$

$\$ 6,250,000.00$

$\$ 20,900,000.00$

$\$ 1,225,000.00$

$\$ 11,000,000.00$

$\$ 4,175,000.00$

$\$ 5,500,000.00$

$\$ 3,200,000.00$

$\$ 6,700,000.00$

$\$ 5,300,000.00$

$\$ 1,605,000.00$

$\$ 5,728,000.00$

$\$ 2,250,000.00$

$\$ 5,587,500.00$

$\$ 3,135,000.00$

$\$ 21,500,000.00$

$\$ 5,000,000.00$

$\$ 4,200,000.00$

$\$ 1,667,500.00$
0.0573

0.416

0.134

0.056

0.398

0.181

0.059

0.067

0.897

0.158

0.323

0.076

0.359

0.037

0.293

0.039

0.238

0.048

0.175

$\$ 38,394,415.36$

$\$ 25,240,384.62$

$\$ 31,529,850.75$

$\$ 83,571,428.57$

$\$ 69,126,884.42$

$\$ 44,198,895.03$

$\$ 36,440,677.97$

$\$ 37,748,177.89$

$\$ 34,328,358.21$

$\$ 79,431,438.13$

$\$ 47,151,898.73$

$\$ 22,012,383.90$

$\$ 26,315,789.47$

$\$ 57,938,718.66$

$\$ 40,540,540.54$

$\$ 35,494,880.55$

$\$ 34,615,384.62$

$\$ 42,731,092.44$

$\$ 41,666,666.67$

$\$ 17,714,285.71$

$\$ 39,995,119.80$

$0.223 \$ 35,874,439.46$

$0.045 \$ \$ 46,666,666.67$

$0.059 \$ 36,779,661.02$

$0.216 \$ 20,370,370.37$

$\$ 34,922,784.38$

0.4

0.217

0.241

0.054

0.115

0.067

0.495

0.38

0.383

0.828

0.489

1.102

0.22

0.404

0.07

0.31

0.86

0.068

0.983

0.29

0.983

0.31

0.551

0.475

0.098

0.19

0.276

0.38

0.137

1.031

0.476

0.269

0.055

$\$ 52,500,000.00$

$\$ 40,046,082.95$

$\$ 9,958,506.22$

$\$ 59,259,259.26$

$\$ 36,956,521.74$

$\$ 17,910,447.76$

$\$ 40,251,515.15$

$\$ 22,666,118.42$

$\$ 16,971,279.37$

$\$ 16,304,347.83$

$\$ 36,809,815.95$

$\$ 34,936,479.13$

$\$ 16,363,636.36$

$\$ 45,792,079.21$

$\$ 40,000,000.00$

$\$ 20,161,290.32$

$\$ 24,302,325.58$

$\$ 18,014,705.88$

$\$ 11,190,233.98$

$\$ 14,396,551.72$

$\$ 5,595,116.99$

$\$ 10,322,580.65$

$\$ 12,159,709.62$

$\$ 11,157,894.74$

$\$ 16,377,551.02$

$\$ 30,147,368.42$

$\$ 8,152,173.91$

$\$ 14,703,947.37$ 


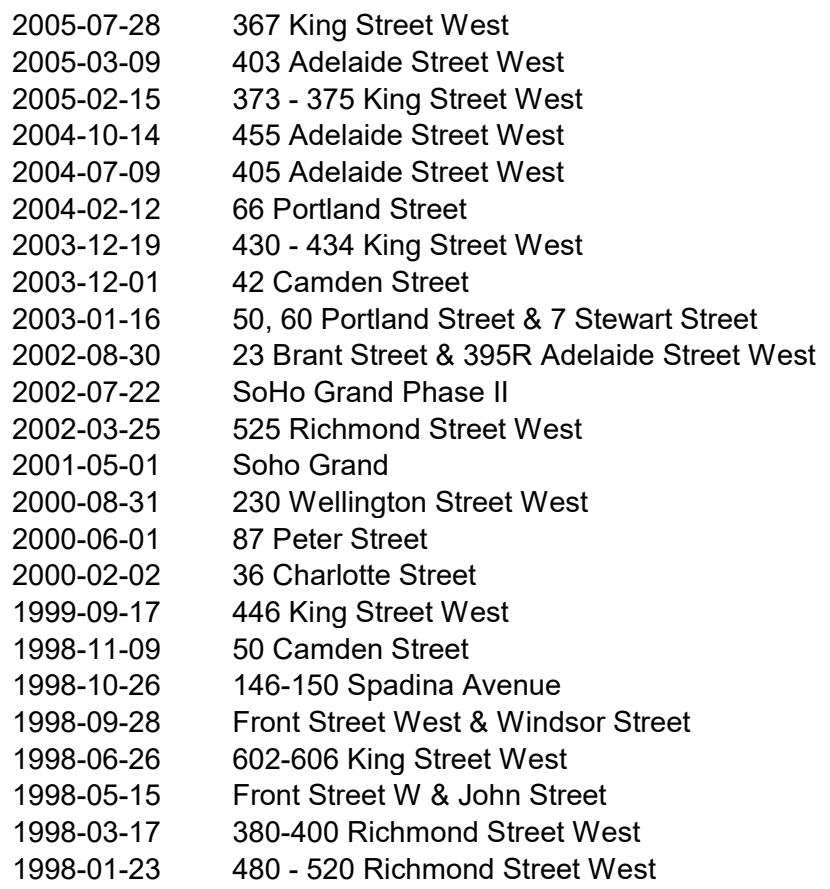

367 King Street West

403 Adelaide Street West

373 - 375 King Street West

455 Adelaide Street West

405 Adelaide Street West

66 Portland Street

430 - 434 King Street West

42 Camden Street

50, 60 Portland Street \& 7 Stewart Street

23 Brant Street \& 395R Adelaide Street West

SoHo Grand Phase II

525 Richmond Street West

Soho Grand

230 Wellington Street West

87 Peter Street

36 Charlotte Street

446 King Street West

50 Camden Street

146-150 Spadina Avenue

Front Street West \& Windsor Street

602-606 King Street West

Front Street W \& John Street

380-400 Richmond Street West

480 - 520 Richmond Street West

$\begin{array}{rrr}\$ 1,667,500.00 & 0.054 & \$ 30,879,629.63 \\ \$ 1,400,000.00 & 0.031 & \$ 45,161,290.32 \\ \$ 2,900,000.00 & 0.248 & \$ 11,693,548.39 \\ \$ 2,700,000.00 & 0.448 & \$ 6,026,785.71 \\ \$ 2,630,820.00 & 0.413 & \$ 6,370,024.21 \\ \$ 2,340,000.00 & 0.3 & \$ 7,800,000.00 \\ \$ 7,400,000.00 & 0.46 & \$ 16,086,956.52 \\ \$ 1,500,000.00 & 0.136 & \$ 11,029,411.76 \\ \$ 4,000,000.00 & 0.622 & \$ 6,430,868.17 \\ \$ 4,800,000.00 & 0.762 & \$ 6,299,212.60 \\ \$ 3,896,992.00 & 0.769 & \$ 5,067,609.88 \\ \$ 2,375,000.00 & 0.264 & \$ 8,996,212.12 \\ \$ 7,103,008.00 & 0.792 & \$ 8,968,444.44 \\ \$ 18,000,000.00 & 0.59 & \$ 30,508,474.58 \\ \$ 2,225,000.00 & 0.233 & \$ 9,549,356.22 \\ \$ 1,250,000.00 & 0.152 & \$ 8,223,684.21 \\ \$ 5,000,000.00 & 0.553 & \$ 9,041,591.32 \\ \$ 1,175,000.00 & 0.215 & \$ 5,465,116.28 \\ \$ 3,600,000.00 & 0.377 & \$ 9,549,071.62 \\ \$ 3,375,000.00 & 0.383 & \$ 8,812,010.44 \\ \$ 3,500,000.00 & 0.62 & \$ 5,645,161.29 \\ \$ 15,100,000.00 & 1.031 & \$ 14,645,974.78 \\ \$ 2,993,750.00 & 0.639 & \$ 4,685,054.77 \\ \$ 2,890,000.00 & 0.947 & \$ 3,051,742.34\end{array}$

$\$ 31,036.00$

$\$ 31,036.00$

$\$ 31.00$

$\$ 23.00$

$\$ 27,529.00$

$\$ 23,567.00$

$\$ 14,440.00$

$\$ 25,668.00$

$\$ 28.00$

$\$ 27.00$

$\$ 31.00$

$\$ 48.00$

$\$ 31.00$

$\$ 24.00$

$\$ 30.00$

$\$ 12.00$

$\$ 38.00$

$\$ 55.00$

$\$ 48.00$

$\$ 15.00$

$\$ 22.00$

$\$ 22,017.00$

$\$ 23,058.00$

$\$ 25,368.00$

$\$ 43,902.00$

$\$ 20,161.00$

$\$ 19,583.00$

$\$ 16,514.00$

$\$ 127,751.00$

$\$ 19,440.00$

$\$ 26,514.00$ 
APPENDIX E - Residential Land Transactions within 500m of Yonge-Eglinton Node Since 1995 (Source: Altus Group, 2018)

\begin{tabular}{|c|c|c|c|c|c|c|}
\hline Date & Municipal Address & Purchase Price & Size (Acres) & Price / Acre & Price / Buildable Sf & Price / Unit \\
\hline 2017-07-31 & 76 Soudan Avenue & $\$ 1,800,000.00$ & 0.039 & $\$ 46,153,846.15$ & & \\
\hline 2017-05-03 & 2434 Yonge Street & $\$ 14,000,000.00$ & 0.17 & $\$ 82,352,941.18$ & $\$ 142.00$ & $\$ 125,887.00$ \\
\hline 2017-05-01 & 74 Soudan Avenue & $\$ 1,450,000.00$ & 0.044 & $\$ 32,954,545.45$ & & \\
\hline 2017-03-30 & 70 Soudan Avenue & $\$ 1,175,000.00$ & 0.038 & $\$ 30,921,052.63$ & & \\
\hline 2017-03-30 & 72 Soudan Avenue & $\$ 1,175,000.00$ & 0.051 & $\$ 23,039,215.69$ & & \\
\hline 2017-02-01 & 39 Roehampton Avenue & $\$ 13,500,000.00$ & 0.246 & $\$ 54,878,048.78$ & $\$ 43.00$ & $\$ 28,404.00$ \\
\hline \multicolumn{2}{|c|}{ Yearly Average } & $\$ 5,516,666.67$ & $\$ 0.10$ & $\$ 56,292,517.01$ & $\$ 92.50$ & $\$ 77,145.50$ \\
\hline 2016-11-28 & 41 Roehampton Avenue & $\$ 4,025,000.00$ & 0.181 & $\$ 22,237,569.06$ & $\$ 43.00$ & $\$ 28,404.00$ \\
\hline 2016-09-08 & 45 Eglinton Avenue East & $\$ 5,350,000.00$ & 0.081 & $\$ 66,049,382.72$ & & \\
\hline 2016-08-31 & 2100 Yonge Street \& 8 Manor Road & $\$ 3,000,000.00$ & 0.106 & $\$ 28,301,886.79$ & & \\
\hline 2016-06-21 & 50 \& 60 Eglinton Avenue West & $\$ 14,620,000.00$ & 0.43 & $\$ 34,000,000.00$ & $\$ 50.00$ & $\$ 36,459.00$ \\
\hline 2016-04-15 & 17 Lillian Street & $\$ 2,300,000.00$ & 0.04 & $\$ 57,500,000.00$ & & \\
\hline 2016-04-15 & 15 Lillian Street & $\$ 2,000,000.00$ & 0.043 & $\$ 46,511,627.91$ & & \\
\hline $2016-02-29$ & 2128 Yonge Street & $\$ 6,500,000.00$ & 0.1922 & $\$ 33,818,938.61$ & & \\
\hline 2016-01-21 & 2444 Yonge Street & $\$ 14,500,000.00$ & 0.246 & $\$ 58,943,089.43$ & $\$ 142.00$ & $\$ 125,887.00$ \\
\hline \multicolumn{2}{|c|}{ Yearly Average } & $\$ 6,536,875.00$ & $\$ 0.16$ & $\$ 43,420,311.81$ & $\$ 78.33$ & $\$ 63,583.33$ \\
\hline $2015-10-26$ & 29 - 31 Soudan Avenue & $\$ 3,400,000.00$ & 0.132 & $\$ 25,757,575.76$ & $\$ 80.00$ & $\$ 67,741.00$ \\
\hline 2015-09-10 & 2440 Yonge Street & $\$ 9,300,000.00$ & 0.129 & $\$ 72,093,023.26$ & $\$ 142.00$ & $\$ 125,887.00$ \\
\hline 2015-07-08 & 55 - 65 Broadway Avenue & $\$ 44,500,000.00$ & 1.324 & $\$ 33,610,271.90$ & $\$ 57.00$ & $\$ 42,625.00$ \\
\hline 2015-02-02 & 2400 Yonge Street \& 35 Roselawn Avenue & $\$ 34,500,000.00$ & 1.402 & $\$ 24,607,703.28$ & $\$ 142.00$ & $\$ 125,887.00$ \\
\hline 2015-01-19 & 2430 Yonge Street & $\$ 7,890,000.00$ & 0.111 & $\$ 71,081,081.08$ & $\$ 142.00$ & $\$ 125,887.00$ \\
\hline \multicolumn{2}{|c|}{ Yearly Average } & $\$ 19,918,000.00$ & $\$ 0.62$ & $\$ 45,429,931.06$ & $\$ 112.60$ & $\$ 97,605.40$ \\
\hline $2014-12-10$ & 177 Roehampton Avenue & $\$ 3,600,000.00$ & 0.066 & $\$ 54,545,454.55$ & $\$ 62.00$ & $\$ 41,599.00$ \\
\hline 2014-11-05 & 31 - 37 Helendale Avenue & $\$ 17,000,000.00$ & 0.396 & $\$ 42,929,292.93$ & $\$ 94.00$ & $\$ 88,624.00$ \\
\hline 2014-11-03 & 2263 Yonge Street & $\$ 11,900,000.00$ & 0.136 & $\$ 87,500,000.00$ & $\$ 61.00$ & $\$ 64,134.00$ \\
\hline 2014-08-14 & 2388 Yonge Street & $\$ 13,232,859.78$ & 0.638 & $\$ 20,741,159.53$ & $\$ 60.00$ & $\$ 56,793.00$ \\
\hline 2014-06-12 & 164 Eglinton Avenue East & $\$ 6,025,000.00$ & 0.121 & $\$ 49,793,388.43$ & & \\
\hline 2014-03-05 & 31 Roehampton Avenue & $\$ 8,500,000.00$ & 0.357 & $\$ 23,809,523.81$ & $\$ 61.00$ & $\$ 64,134.00$ \\
\hline 2014-02-05 & 89 Roehampton Avenue & $\$ 2,000,000.00$ & 0.114 & $\$ 17,543,859.65$ & & \\
\hline \multicolumn{2}{|c|}{ Yearly Average } & $\$ 8,893,979.97$ & $\$ 0.26$ & $\$ 42,408,954.13$ & $\$ 67.60$ & $\$ 63,056.80$ \\
\hline $2012-12-13$ & 150 Eglinton Avenue East & $\$ 26,500,000.00$ & 0.743 & $\$ 35,666,218.03$ & $\$ 66.00$ & $\$ 64,477.00$ \\
\hline 2012-12-12 & 132-142 Soudan Street \& 11 Lillian Street & $\$ 6,390,000.00$ & 0.182 & $\$ 35,109,890.11$ & $\$ 57.00$ & $\$ 49,535.00$ \\
\hline 2012-11-13 & 161 Roehampton Avenue & $\$ 3,375,000.00$ & 0.069 & $\$ 48,913,043.48$ & $\$ 62.00$ & $\$ 41,599.00$ \\
\hline 2012-10-29 & 151 Roehampton Avenue & $\$ 1,600,000.00$ & 0.094 & $\$ 17,021,276.60$ & $\$ 62.00$ & $\$ 41,599.00$ \\
\hline 2012-08-09 & 157 Roehampton Avenue & $\$ 1,312,500.00$ & 0.081 & $\$ 16,203,703.70$ & $\$ 62.00$ & $\$ 41,599.00$ \\
\hline 2012-07-17 & $\begin{array}{l}165 \& 173 \text { Roehampton Avenue, } 140 \text { \& } 142 \text { Redpath } \\
\text { Avenue }\end{array}$ & $\$ 7,443,881.41$ & 0.337 & $\$ 22,088,668.87$ & $\$ 62.00$ & $\$ 41,599.00$ \\
\hline 2012-06-18 & 2287 Yonge Street & $\$ 7,000,000.00$ & 0.098 & $\$ 71,428,571.43$ & $\$ 61.00$ & $\$ 64,134.00$ \\
\hline 2012-04-12 & 167-171 Roehampton Avenue & $\$ 4,300,000.00$ & 0.122 & $\$ 35,245,901.64$ & $\$ 62.00$ & $\$ 41,599.00$ \\
\hline \multicolumn{2}{|c|}{ Yearly Average } & $\$ 7,240,172.68$ & $\$ 0.22$ & $\$ 35,209,659.23$ & $\$ 61.75$ & $\$ 48,267.63$ \\
\hline 2011-12-19 & 90 Eglinton Avenue West & $\$ 14,500,000.00$ & 0.431 & $\$ 33,642,691.42$ & $\$ 60.59$ & $\$ 58,704.45$ \\
\hline 2011-11-16 & 31-35 Helendale Avenue & $\$ 5,700,000.00$ & 0.333 & $\$ 17,117,117.12$ & $\$ 32.00$ & $\$ 24,675.00$ \\
\hline 2011-10-31 & 25 Roehampton Avenue & $\$ 5,950,000.00$ & 0.262 & $\$ 22,709,923.66$ & $\$ 61.00$ & $\$ 64,134.00$ \\
\hline 2011-10-27 & 2131 Yonge Street \& 32 Hillsdale Avenue East & $\$ 40,360,800.00$ & 1.569 & $\$ 25,723,900.57$ & $\$ 80.00$ & $\$ 67,741.00$ \\
\hline 2011-10-12 & $2281-2285$ Yonge Street & $\$ 8,600,000.00$ & 0.343 & $\$ 25,072,886.30$ & $\$ 61.00$ & $\$ 64,134.00$ \\
\hline 2011-09-27 & 10 Eglinton Avenue East & $\$ 8,500,000.00$ & 0.121 & $\$ 70,247,933.88$ & $\$ 61.00$ & $\$ 64,134.00$ \\
\hline 2011-08-17 & $2360-2378$ Yonge Street & $\$ 16,500,000.00$ & 0.364 & $\$ 45,329,670.33$ & $\$ 94.00$ & $\$ 88,624.00$ \\
\hline 2011-08-08 & $2273-2279$ Yonge Street & $\$ 10,200,000.00$ & 0.143 & $\$ 71,328,671.33$ & $\$ 61.00$ & $\$ 64,134.00$ \\
\hline \multicolumn{2}{|c|}{ Yearly Average } & $\$ 13,788,850.00$ & $\$ 0.45$ & $\$ 38,896,599.33$ & $\$ 63.82$ & $\$ 62,035.06$ \\
\hline $2010-12-16$ & 30 Roehampton Avenue & $\$ 24,400,000.00$ & 0.821 & $\$ 29,719,853.84$ & $\$ 76.00$ & $\$ 67,590.00$ \\
\hline 2007-10-04 & 70 Roehampton Avenue & $\$ 22,336,607.88$ & 5.318 & $\$ 4,200,189.52$ & $\$ 45.00$ & $\$ 48,558.00$ \\
\hline 2007-02-02 & $\begin{array}{l}58,60,64 \& 68 \text { Orchard View Boulevard and } 439 \& \\
441 \text { Duplex Avenue }\end{array}$ & $\$ 3,000,000.00$ & 0.294 & $\$ 10,204,081.63$ & $\$ 18.00$ & $\$ 13,453.00$ \\
\hline 2006-05-01 & Duplex Avenue and Berwick Avenue & $\$ 9,850,000.00$ & 1.1856 & $\$ 8,308,029.69$ & & \\
\hline $2005-01-24$ & 152 Roehampton Avenue & $\$ 5,370,000.00$ & 0.429 & $\$ 12,517,482.52$ & $\$ 50.00$ & $\$ 37,552.00$ \\
\hline 2002-03-13 & 152 Roehampton Avenue & $\$ 2,800,000.00$ & 0.435 & $\$ 6,436,781.61$ & $\$ 23.00$ & $\$ 15,909.00$ \\
\hline $2002-02-26$ & 58-68 Orchard View Blvd \& 439-441 Duplex Ave & $\$ 1,825,000.00$ & 0.297 & $\$ 6,144,781.14$ & & \\
\hline 2000-06-06 & 2195 Yonge Street & $\$ 15,000,000.00$ & 1.922 & $\$ 7,804,370.45$ & $\$ 36.00$ & \\
\hline $1997-12-22$ & 123 Eglinton Avenue East & $\$ 3,750,000.00$ & 0.963 & $\$ 3,894,081.00$ & $\$ 16.00$ & $\$ 20,270.00$ \\
\hline $1997-04-29$ & 43 Eglinton Avenue East & $\$ 2,450,000.00$ & 0.321 & $\$ 7,632,398.75$ & $\$ 23.00$ & \\
\hline 1995-05-01 & 110 Redpath Avenue & $\$ 10,233,000.00$ & 1.9 & $\$ 5,385,789.47$ & $\$ 62.00$ & $\$ 55,614.00$ \\
\hline
\end{tabular}


APPENDIX F - Residential Land Transactions within 500m of Bloor-Dundas Node Since 1995 (Source: Altus Group, 2018)

\begin{tabular}{|c|c|c|c|c|c|c|}
\hline Date & Municipal Address & Purchase Price & Size (Acres) & Price / Acre & Price / Buildable Sf & Price / Unit \\
\hline $2017-10-02$ & 1630 Bloor Street West & $\$ 1,500,000.00$ & 0.16 & $\$ 9,375,000.00$ & & \\
\hline $2017-07-28$ & 2252 Dundas Street West & $\$ 5,500,000.00$ & 0.121 & $\$ 45,454,545.45$ & & \\
\hline 2016-04-08 & 1550 Bloor Street West & $\$ 1,601,000.00$ & 0.03 & $\$ 53,366,666.67$ & & \\
\hline 2016-01-15 & 1546 - 1548 Bloor Street West & $\$ 2,200,000.00$ & 0.058 & $\$ 37,931,034.48$ & & \\
\hline 2015-08-31 & 1542 - 1544 Bloor Street West & $\$ 1,800,000.00$ & 0.046 & $\$ 39,130,434.78$ & & \\
\hline 2015-03-31 & 424 - 430 Roncesvalles Avenue \& 76 Howard Park Avenue & $\$ 4,687,500.00$ & 0.528 & $\$ 8,877,840.91$ & $\$ 60.00$ & $\$ 58,460.00$ \\
\hline 2015-03-31 & 422 Roncesvalles Avenue & $\$ 1,100,000.00$ & 0.029 & $\$ 37,931,034.48$ & $\$ 60.00$ & $\$ 58,460.00$ \\
\hline 2013-01-22 & 26 Ernest Avenue & $\$ 5,000,000.00$ & 1.829 & $\$ 2,733,734.28$ & & $\$ 45,455.00$ \\
\hline 2013-2017 AVERAGE & & $\$ 2,923,562.50$ & $\$ 0.35$ & $\$ 29,350,036.38$ & $\$ 60.00$ & $\$ 54,125.00$ \\
\hline 2010-01-14 & 370 Wallace Avenue & $\$ 5,800,000.00$ & 3.133 & $\$ 1,851,260.77$ & & \\
\hline 2009-02-06 & 2376 Dundas Street West & $\$ 6,250,000.00$ & 1.45 & $\$ 4,310,344.83$ & $\$ 21.00$ & $\$ 16,067.00$ \\
\hline 2007-09-14 & 1540 Bloor Street West & $\$ 6,000,000.00$ & 0.479 & $\$ 12,526,096.03$ & $\$ 22.00$ & $\$ 20,478.00$ \\
\hline 2005-02-08 & 437 Roncesvalles Avenue & $\$ 2,310,000.00$ & 0.356 & $\$ 6,488,764.04$ & $\$ 22.00$ & $\$ 25,385.00$ \\
\hline $2003-11-26$ & 351 Wallace Avenue & $\$ 1,150,000.00$ & 2.308 & $\$ 498,266.90$ & & \\
\hline 2001-10-05 & 2477-2505 Dundas Street West & $\$ 1,600,000.00$ & 0.724 & $\$ 2,209,944.75$ & $\$ 25.00$ & \\
\hline 2001-05-07 & 1380 Bloor Street West & $\$ 1,600,000.00$ & 0.662 & $\$ 2,416,918.43$ & $\$ 37.00$ & $\$ 40,000.00$ \\
\hline $2001-02-28$ & 437 - 439 Roncesvalles Avenue & $\$ 2,000,000.00$ & 0.354 & $\$ 5,649,717.51$ & $\$ 43.00$ & \\
\hline 1999-03-26 & 1379-1395 Bloor Street West & $\$ 3,350,000.00$ & 4.578 & $\$ 731,760.59$ & & \\
\hline 1998-10-16 & 371 Wallace Avenue & $\$ 1,200,000.00$ & 0.837 & $\$ 1,433,691.76$ & $\$ 28.00$ & $\$ 27,273.00$ \\
\hline 1998-08-18 & 1 Rankin Crescent & $\$ 1,700,000.00$ & 0.911 & $\$ 1,866,081.23$ & $\$ 17.00$ & $\$ 16,505.00$ \\
\hline 1998-2010 AVERAGE & & $\$ 2,996,363.64$ & $\$ 1.44$ & $\$ 3,634,804.26$ & $\$ 26.88$ & $\$ 24,284.67$ \\
\hline
\end{tabular}




\section{WORKS CITED}

Affordable Housing Office. (2017). Creating 298 Affordable Rental Homes in Toronto: Results of the 2017 Open Door Call for Applications. Retrieved from:

https://www.toronto.ca/legdocs/mmis/2017/ah/bgrd/backgroundfile-106681.pdf

Altus. (2018). Construction Cost Guide. Retrieved from:

http://www.altusgroup.com/news_insights/construction-cost-guide-2018

Altus Group. (2018). GTA State of the Market 2018. Retrieved from:

https://realinfo.realnet.ca/client/marketReports/marketBriefings.do

Applying for Open Door. (2018). Retrieved from:

https://www.toronto.ca/wp-content/uploads/2018/01/9572-Open-Door-Application-Package-

2018.pdf

Bill 7 - Response to the Proposed Inclusionary Zoning Regulation. (2018). Retrieved from: https://www.toronto.ca/legdocs/mmis/2018/pg/bgrd/backgroundfile-111695.pdf

Canada Mortgage and Housing Corporation. (2017). Rental Market Reports - Canada and Provincial Highlights. Retrieved from:

https://www03.cmhc-

schl.gc.ca/catalog/productList.cfm?cat=59\&lang=en\&sid=CU4PM6tHsgVmbclOCwYfxejKlyuCGL gHTyAOWAUBpuMuWGmjZ299iOYhxNqvVLHM\&fr=1521748327565

Canada Mortgage and Housing Corporation. (2018). Mortgage Payment Calculator. Retrieved from: https://www.cmhc-schl.gc.ca/en/co/buho/buho_021.cfm

Canada Mortgage and Housing Corporation. (2018). Stress Testing at CMHC. Retrieved from: https://www.cmhc-schl.gc.ca/en/corp/nero/jufa/jufa_036.cfm

CBC News. (2017). Wondering what the mega-development at Bloor and Dundas West might look like? Here's a sneak peek. Retrieved from:

http://www.cbc.ca/news/canada/toronto/dundas-bloor-development-choice-public-consultation1.4355468

Chief Planner \& Executive Director. (2015). Planning Act - Proposed Amendments Introduced Through Bill 73, Smart Growth for Our Communities Act. Retrieved from: https://www.toronto.ca/legdocs/mmis/2015/pg/bgrd/backgroundfile-79744.pdf

City Council. (2015). Ahead of the Curve: Preparing for Inclusionary Zoning for the City of Toronto Retrieved from: https://www.toronto.ca/legdocs/mmis/2015/pg/bgrd/backgroundfile-80023.pdf

City Planning Division. (2017). Midtown in Focus: Proposed Yonge-Eglinton Secondary Plan Update. Retrieved from:

https://www.toronto.ca/legdocs/mmis/2017/pg/bgrd/backgroundfile-108435.pdf

Commissioner of Urban Planning and Development Services. (1999). The Mayor's Homelessness Action Task Force Final Report: Recommendations and Policy Directions related to the Housing Policies of the Official Plan. Retrieved from: 
https://www.toronto.ca/legdocs/1999/agendas/committees/cn/cn990503/it001.htm

Craggs, S. (2018). CBC News - Ontario's new rules to help affordable housing shortage won't work in Hamilton, city says. Retrieved from:

http://www.cbc.ca/news/canada/hamilton/inclusionary-zoning-1.4545625

David Paul Rosen \& Associates. (2017). Land Value Capture \& Inclusionary Zoning

Development Charge By-law Review. (2018). Retrieved from:

https://www.toronto.ca/city-government/budget-finances/city-finance/development-charges/2017development-charges-bylaw-review/

Director, Community Planning. (2017). King Spadina Secondary Plan Update - Draft Policy Directions. Retrieved from:

https://www.toronto.ca/legdocs/mmis/2017/te/bgrd/backgroundfile-106496.pdf

Housing Opportunities Toronto. (2010). An Affordable Housing Action Plan. Retrieved from: https://web.toronto.ca/wp-content/uploads/2017/08/8f61-Housing-opportunities-to.pdf

Housing Opportunities Toronto. (2016). Progress Report 2016. Retrieved from: https://www.toronto.ca/wp-content/uploads/2017/11/91b4-HOT-Progress-Report2016.pdf

Gordon, J. (March 13, 2017). In High Demand: Addressing the demand factors behind Toronto's housing affordability problem. Ryerson City Building Institute. Retrieved April 2, 2017.

GO Transit. (2016). Info to GO. Retrieved from: http://www.infogo.gov.on.ca/infogo/

Grzincic, N. \& Tulk, C. (2017). Toronto Star - Do your neighbours make more than you? Search our map of income in the GTA. Retrieved from: https://www.thestar.com/news/gta/2017/11/09/do-your-neighbours-make-more-than-you-searchour-map-of-income-in-the-gta.html

Kalinowski, T. (2017, September 19). The top 5 Toronto intersections for condo resales. Retrieved September 27, 2017, from https://www.thestar.com/business/real_estate/2017/09/19/the-top-5-torontointersections-for-condo-re-sales.html

Keating, W. D. (1986). Linking Downtown Development to Broader Community Goals: An Analysis of Linkage Policy in Three Cities. 52 (2).

Malone Given Parsons Ltd. (1991). Inclusionary zoning study for housing in the city of Toronto: consultant's study: final report. Retrieved from: https://www.library.yorku.ca/find/Record/1039231

Micallef, S. (2016). Toronto Star - A colourful addition deep inside the Yonge Eglinton Centre Retrieved from: https://www.thestar.com/life/2016/02/20/yonge-eglinton-centre-nowhere-spaces-are-sometimessomewhere.html

Milczyn, P. (2018). Ontario Minister Explains Inclusionary Zoning Rationale. Retrieved from: https://www.thestar.com/opinion/contributors/2018/01/30/ontario-housing-minister-explainsinclusionary-zoning-rationale.html 
Ministry of Housing. (2016). Inclusionary Zoning. Retrieved September 27th, 2017, from http://www.mah.gov.on.ca/Page13790.aspx

Ministry of Municipal Affairs. (2005). Provincial Policy Statement. Retrieved from: http://www.mah.gov.on.ca/Page5496.aspx

Ministry of Municipal Affairs. (2017). Growth Plan for Greater Golden Horseshoe. Retrieved from:

http://placestogrow.ca/index.php?option=com_content\&task=view\&id=430\&ltemid=14

Myers, B. (2017). The Market Manuscript. Fortress Real Developments. Retrieved October 20, 2017.

National Housing Strategy. (2017). Retrieved from:

https://www.placetocallhome.ca/pdfs/Canada-National-Housing-Strategy.pdf

Open Door Information Session. (2018). Retrieved from:

https://www.toronto.ca/wp-content/uploads/2018/02/8bbf-ODInfoSession-Feb-20-2018.pdf

Planning and Transportation Committee. (2006). Proposed Growth Plan for the Greater Golden Horseshoe. Retrieved from:

https://www.toronto.ca/legdocs/2006/agendas/council/cc060131/plt1rpt/cl004.pdf

Ratcliffe, J, Stubbs, M, Shepherd, M. (2004) Taylor \& Francis - Urban Planning and Real Estate Development

Smith, D. (2017). Lost Angeles Times - Local. Retrieved from:

http://www.latimes.com/local/lanow/la-me-In-linkage-fee-city-council-20171212-htmlstory.html

Thaden, E., \& Wang, R. (2017). Inclusionary Zoning in the United States: Prevalence, Impact, and Practices. Lincoln Institute of Land Policy. Retrieved October 20, 2017, from http://www.lincolninst.edu/publications/working-papers/inclusionary-housing-united-states

Toronto Official Plan. (2015). Retrieved from:

https://www.toronto.ca/wp-content/uploads/2017/11/99b3-cp-official-plan-volume-1consolidation.pdf

Urban Toronto. (2017). Photo Of The Day: Zooming Up Spadina Avenue Between King And College. Retrieved from:

http://urbantoronto.ca/news/2011/08/photo-day-zooming-spadina-avenue-between-king-andcollege

Williams, Stockton, et al. (2016) The Economics of Inclusionary Development. Washington, DC:

Urban Land Institute. 